\title{
The diversity of Australian Mesozoic bennettitopsid reproductive organs
}

\author{
Stephen McLoughlin ${ }^{1}$ (D) Christian Pott $^{1} \cdot \operatorname{Ian}_{\text {H. Sobbe }}{ }^{2}$
}

Received: 4 February 2017 /Revised: 20 April 2017 / Accepted: 15 May 2017 /Published online: 20 July 2017

(C) The Author(s) 2017. This article is an open access publication

\begin{abstract}
Several dispersed reproductive organs of bennettitopsid gymnosperms are described and illustrated from Triassic to Cretaceous strata of Australia: Williamsonia eskensis sp. nov. (Middle Triassic), Williamsonia ipsvicensis sp. nov. (Upper Triassic), Williamsonia durikaiensis sp. nov. (Lower Jurassic), Williamsonia sp. (Lower Jurassic), Williamsonia rugosa sp. nov. (Middle Jurassic), Williamsonia gracilis sp. nov. (Lower Cretaceous), Cycadolepis ferrugineus sp. nov. (Lower Jurassic), Cycadolepis sp. (Lower Cretaceous), and Fredlindia moretonensis Shirley 1898 comb. nov. (Upper Triassic). Among these, W. eskensis appears to represent the oldest bennettitalean reproductive structure yet identified. Although global floras expressed less provincialism during the Mesozoic and many genera are cosmopolitan, Australian bennettopsid species appear to have been endemic based on the morphological characters of the reproductive structures. Bennettopsids have a stratigraphic range of around 210 million years in Australia and are widely and abundantly represented by
\end{abstract}

This article is a contribution to the special issue "Jurassic biodiversity and terrestrial environments"

Stephen McLoughlin

steve.mcloughlin@nrm.se

Christian Pott

christian.pott@nrm.se

Ian H. Sobbe

ian.sobbe1@bigpond.com

1 Department of Palaeobiology, Swedish Museum of Natural History, Box 50007, SE-104 05 Stockholm, Sweden

2 Ancient Environments, Queensland Museum, PO Box 3300, South Brisbane, 4101 Qld, Australia, and School of Earth and Environmental Sciences, University of Queensland, St Lucia 4072, Australia leaf fossils, but only around 20 specimens of reproductive structures, of which half are attributed to Fredlindia, have been recovered from that continent's geological archive. The extremely low representation of reproductive organs vis-à-vis foliage is interpreted to reflect a combination of physical disintegration of the seed-bearing units while attached to the host axis and, potentially, extensive vegetative reproduction in bennettopsids growing at high southern latitudes during the Mesozoic.

Keywords Bennettitales $\cdot$ Fredlindiales $\cdot$ Reproductive biology $\cdot$ Floral diversity $\cdot$ New species $\cdot$ Williamsonia

\section{Introduction}

Bennettitales are an extinct group of seed plants with superficially cycad-like foliage. They are distinguished from Cycadales by their compact, flower-like, reproductive organs (Taylor et al. 2009) and the key apomorphy of syndetocheilic (brachyparacytic) as opposed to haplocheilic stomata (Thomas and Bancroft 1913; Florin 1933). Bennettitales appeared in the early Mesozoic, although their origins remain ambiguous. The oldest occurrences of the order based on fossil reproductive structures are from Carnian strata of the Alps and South Africa (Crane 1985, 1988; Anderson and Anderson 2003; Pott 2014b; Pott et al. 2010a, 2017), although specimens documented in this study indicate an earlier origin. Pinnate leaves with oblong-linear, parallel-veined segments of cycadalean or bennettitalean aspect occur in various late Palaeozoic and Early to Middle Triassic fossil assemblages (Taylor et al. 2009). However, bennettitalean affinities have not been confirmed for any of these leaves by cuticular details (Pott et al. 2010b). Bennettitales died out in most parts of the world by the end of the Cretaceous (Watson and Sincock 1992; Anderson et al. 1999; McLoughlin et al. 2010; Pott 
et al. 2010a, 2014), although at least one taxon appears to have persisted in high-latitude refugia of Tasmania and eastern Australia until the Oligocene (McLoughlin et al. 2011).

Two major families are traditionally recognised within Bennettitales (although Anderson et al. (2007) recognised seven families): Cycadeoidaceae and Williamsoniaceae. The latter family is most likely paraphyletic incorporating several fossil-taxa that may not be closely related (Pott 2014a). Current systematic treatments separate the two major families mainly on overall growth form and architecture of the reproductive structures. Cycadeoidaceae had bisexual reproductive organs that were embedded deeply among persistent leaf bases on short, stout, rarely branched stems. In some cases, the flower-like structures of these plants may never have opened fully and perhaps underwent selfpollination (Delevoryas 1968). In contrast, Williamsoniaceae produced either bisexual or separate male and female reproductive organs that were exposed in branch axils on divaricating, thin-branched, shrubby plants (Pott 2014a; Pott and McLoughlin 2014). Williamsoniaceae may have arisen earlier than Cycadeoidaceae (Crane 1985; Pott et al. 2007b, 2010a, 2017; Pott 2014b, 2016). The latter appears to be a derived group restricted to western Laurasia (Wieland 1916; Watson and Sincock 1992), although perhaps extending to the Tethyan margin of northern Gondwana (Sahni 1932). Assignment of these groups to a single order is based primarily on the syndetocheilic stomata on leaves and similar architecture of the foliage and bisexual flowers of some members of both groups.

The first reproductive organs of Bennettitales were recorded and summarised by Williamson (1870) and Carruthers (1870) from the Jurassic of Yorkshire and the Jurassic and Cretaceous of the Isles of Wight and Portland. Carruthers (1870) assigned the fossils to the families (tribus) Williamsonieae and Bennettiteae, being the first to recognise their distinct differences from cycads. However, it took more than 20 years until Engler (1892) established the order Bennettitales as distinct from Cycadales. Carruthers (1870) was also the first to recognise the striking differences in reproductive organ arrangement and stem architecture between Cycadeoidaceae and Williamsoniaceae. These details were later refined by Nathorst (1888). The Yorkshire material was represented only by compressions, whereas the material from the south coast of England included permineralized axes and reproductive structures.

Permineralized examples of axes with embedded cones (of cycadeoidacean nature) from Europe were initially studied by Carruthers (1870), Solms-Laubach (1891), Raciborski (1893) and Lignier (1894), whereas similar stems and cones from North America have been analysed extensively by Wieland $(1906,1916)$ and later by Delevoryas $(1963,1968)$ and Crepet $(1972,1974)$. Detached permineralized cones (usually assigned to Williamsoniaceae) are less common and were initially studied by Wieland $(1909,1911)$ with re-analysis by Delevoryas and Gould (1973). Watson and Sincock (1992) and Watson and Lydon (2004) studied and revised in detail the cycadeoidacean trunk genera with embedded cones from northwestern Europe, and later Rothwell and Stockey (2002) and Stockey and Rothwell (2003) studied isolated permineralized specimens of both families from North America and reevaluated characters for phylogenetic placement of the fossils (See Pott and Axsmith 2015). Permineralized material from India and Japan have also been studied over a long period, beginning with the works of Sahni (1932) and Sahni and Rao (1934), up to the detailed analyses of Bose $(1966,1968)$, Sharma (1970, 1973, 1975, 1977), Bose et al. (1984) and Saiki and Yoshida (1999). Anatomical studies have been supplemented by numerous analyses of epidermal features of compression fossils (e.g. Nathorst 1902; Harris 1932, 1969; Watson and Sincock 1992; Pedersen et al. 1989; Schweitzer and Kirchner 2003; Pott et al. 2007a, b, 2010a, 2016, 2017; Pott and McLoughlin 2009; Pott 2014a, 2016). However, a large number of bennettitalean remains are preserved as impressions that lack anatomical or micromorphological details.

Bennettitales have been the focus of renewed interest in recent years owing to their potentially important role in understanding the relationships of Gnetales and angiosperms to other seed plants. In several analyses based on morphological characters, Bennettitales are placed with angiosperms, Gnetales, and, in some cases, with the extinct Erdtmanithecales and Pentoxylales in a monophyletic group termed the anthophytes (Crane 1985; Hilton and Bateman 2006; Friis et al. 2007, 2009). However, the anthophyte concept is not universally accepted and there is currently no consensus regarding interrelationships among the various groups of extant and extinct seed plants (Donoghue and Doyle 2000; Doyle 2006; Rothwell et al. 2009; Crepet and Stevenson 2010). Moreover, other analyses, especially those incorporating molecular data, do not find strong support for an anthophyte clade (Mathews 2009; Rothwell et al. 2009). Major problems with attempts to resolve seed plant phylogeny relate to inadequate knowledge of the many extinct groups; thus, many fossil taxa included in morphology-based analyses are in urgent need of re-evaluation using modern techniques. Controversies remain about the homology of key bennettitalean reproductive characters (Friis et al. 2007; Rothwell et al. 2009; Pott 2016). Alternative relationships with Cycadales have even been suggested recently for Bennettitales (e.g. Crepet and Stephenson 2010), reprising an old hypothesis based on superficial similarities between the leaves of these groups (e.g. Wieland 1906, 1916).

Bennettitopsid foliage is abundant and widespread in Australian mid-Mesozoic continental strata (Gould 1975; Hill et al. 1999; McLoughlin and McNamara 2001), and numerous taxa have been identified and described (Douglas 1969; Tidwell et al. 1987; McLoughlin 1996; Pole and Douglas 1999; McLoughlin et al. 2002; McLoughlin and Pott 2009). Australia is notable for hosting some of the oldest (mid-Triassic) and youngest (Oligocene) fossil representatives 
of this group (Holmes and Anderson 2008; McLoughlin et al. 2011). Bennettitales-like monosulcate pollen, generally attributed to Cycadopites, is also a common background (but rarely dominant) component of many Australian mid-Mesozoic palynoassemblages (Burger 1980, 1994). However, it remains difficult to distinguish between the dispersed pollen of Bennettitales, Cycadales and Ginkgoales (Balme 1995); hence, palynology cannot provide a clear signal of bennettitalean diversity and abundance in the Australian fossil record. In contrast, there have been few reports and no formal descriptions of fossil benettitopsid reproductive organs from that continent. This study aims to document the distribution and diversity of fossil bennettitalean reproductive organs in Australian sedimentary basins, describe their range of preservational states, evaluate their potential for contributing anatomical characters for phylogenetic analyses and assess whether such remains are genuinely scarce in that continent's stratigraphic record. We evaluate potential reasons for their apparent scarcity and assess the implications for bennettitopsid palaeoecology.

\section{Material and methods}

We undertook surveys of the Mesozoic fossil plant collections held in the major state museums and geological surveys of Australia. The first author also carried out field investigations and sampling over the past three decades at several localities where fossil bennettitalean foliage is abundantly represented (viz., Boola Boola Forest, Victoria; Nymboida, New South Wales; Durikai, Dinmore and the Esk Trough, Queensland; and Gingin and Broome, Western Australia). We also compared the Australian fossils with bennettitalean fertile organs held in the collections of the Geological Survey of India (Calcutta), the Birbal Sahni Institute of Palaeobotany (Lucknow), the Swedish Museum of Natural History (Stockholm), the Shandong Tianyu Museum of Natural History (Pingyi), the Museum of Natural History (Vienna) and the Geological Survey of Austria (Vienna) in order to evaluate whether taxa were shared across large geographic distances.

Material illustrated in this study is stored in various institutions according to the following prefixes: QM-Queensland Museum, UQF-University of Queensland and GSQGeological Survey of Queensland collections all housed in the Queensland Museum, Brisbane; GA-Geoscience Australia, Canberra; and NRM-Swedish Museum of Natural History, Stockholm. Most of the specimens illustrated in this study were collected by staff of the Queensland Museum, University of Queensland and Geoscience Australia over the past century during regional geological mapping programs or palaeobotanical investigations specifically targeting plant-rich or coal-bearing strata. QMF58844 was found by private collector Robert
Knezour, Ipswich, Queensland, and donated to the Queensland Museum. Several additional dispersed bracts were collected by the authors from the Marburg Subgroup at Durikai, Queensland, in 1990 and 2014.

Specimens were photographed using a polarising filter under strong unilateral low-angle light from the upper left to accentuate surface ornamentation, and in some cases, a secondary light from the middle right was used to eliminate strong shadows. Replicas of some specimens were obtained by preparing latex or dental polymer (hydrophilic vinyl polysiloxane) casts from natural moulds. The casts were photographed with a Zeiss Stemi SV 11 microscope or dissected, mounted on aluminium stubs, coated with gold and studied with a Hitachi S-4300 field emission scanning electron microscope at the Swedish $\mathrm{Mu}-$ seum of Natural History.

\section{Terminology}

We follow the descriptive terminology of Watson and Sincock (1992), Pott et al. (2010a) and Pott (2014a) for bennettitalean morphology. We use the terms 'flower' to refer to the cupshaped reproductive structures of bennettitaleans, and 'perianth' for the ring of bracts or scale leaves (involucrum) forming the outer part of these structures. The use of the term 'flower' for bennettitalean reproductive structures extends back to the 1800 s (e.g. in the pioneering work of Wieland 1899) and has been used extensively in recent reviews of the group (Watson and Sincock 1992; Pott et al. 2010a; Pott 2014a). We employ the terms 'receptacle' for the central tissue on which the ovules are inserted, and 'gynoecium' for the receptacle and its attached ovules and interseminal scales. However, we do not imply homology of these structures with homonymous features in the reproductive organs of other seed plants.

\section{Geological setting}

The fossils studied herein derive from several stratigraphic units ranging in age from Middle Triassic to Early Cretaceous that occur in various sedimentary basins through eastern Australia (Fig. 1). The ages, depositional settings and palaeolatitudes of these units are briefly summarised below, since these are significant in understanding the biostratigraphic, palaeoenvironmental and palaeogeographic contexts of the bennettitalean remains.

\section{Esk Formation}

A single bennettitalean flower (QMF58844) from Paddys Gully, near the Coominya turnoff from the Brisbane Valley Highway near Esk, southeast Queensland (Fig. 1), derives from the Esk Formation. This unit consists of interbedded 
Fig. 1 Map of Australia showing the distribution of Triassic, Jurassic and Cretaceous sedimentary rock exposures and indicating the main sites yielding bennettitopsid reproductive structures and foliage

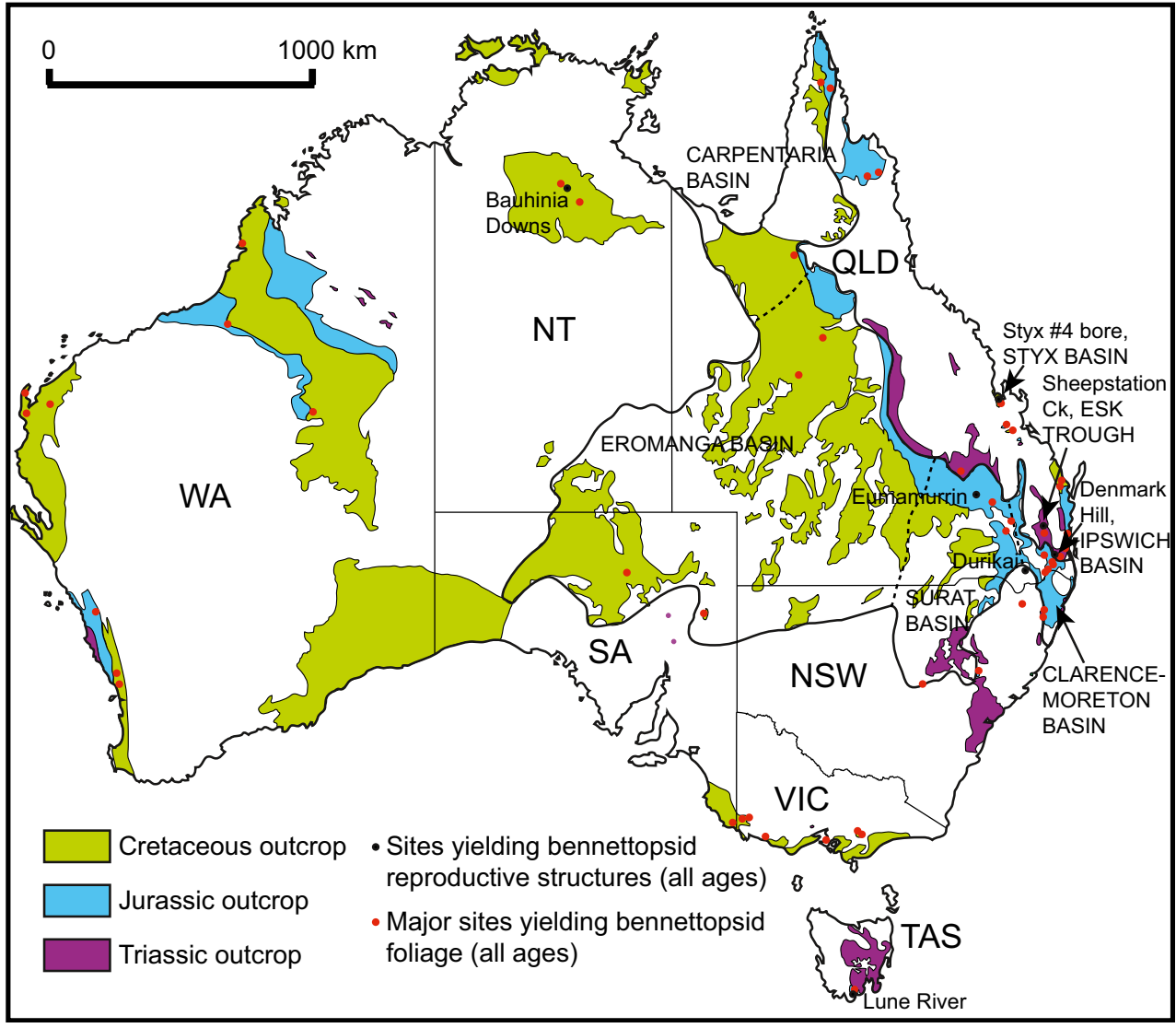

conglomerates, sandstones and mudstones deposited in fluvial systems within the Esk Trough - a narrow, NNW-SSE trending, graben-like structure that has been interpreted as a relictual southerly extension of the Bowen Basin foreland basin complex (Campbell et al. 1999). The Esk Formation partly overlies and partly interdigitates with the Bryden Beds and Neara Volcanics. The precise relationships of these units within much of the basin are uncertain owing to deeply weathered and discontinuous exposures. Spore-pollen assemblages indicate a Middle Triassic (Anisian-Ladinian: c. 246-229 Ma) age for the Esk Formation (Jersey 1975), and this is consistent with a radiometric date of 236-242 \pm 5 Ma from extrusive igneous rocks in the underlying and partly interdigitating Neara Volcanics (Webb 1982a). The Esk Formation hosts diverse fossil leaf and axis assemblages incorporating sphenophytes, several families of ferns, Cycadales, Bennettitales, possible Pentoxylales, Umkomasiales, Matatiellales, Fraxinopsiales, Nataligmales, Ginkgoales and at least two families of conifers (Walkom 1924, 1928; Hill et al. 1965; Rigby 1977; Webb 1982b, 1983, 2001). The Esk Formation was deposited at a palaeolatitude of $c$. $65^{\circ} \mathrm{S}$ (Veevers 2000).

\section{Blackstone Formation}

A single putative bennettitalean 'flower' derives from the Denmark Hill Conservation Reserve in the suburbs of
Ipswich, southeast Queensland (Fig. 1). Fossils of plants and insects have been recovered from strata of the Blackstone Formation (upper part of the Ipswich Coal Measures) at Denmark Hill in the Ipswich Basin for more than 100 years. Numerous plant macrofossils have been documented from this site by Shirley (1898), Walkom (1917), Jones and de Jersey (1947), Hill et al. (1965) and Pattemore and Rigby (2005). The extensive fossil insect fauna was summarised by Jell (2004). The geology of the site was described in detail by Dunstan (1916) who noted that the fossiliferous beds at Denmark Hill represent a lacustrine package between the Bluff and Aberdare coal seams in the upper part of the Blackstone Formation. Spore-pollen assemblages recovered from the Blackstone Formation by Jersey (1970) are referable to the Craterisporites rotundus Zone of Carnian to earliest Norian age (Helby et al. 1987). The Blackstone Formation at Denmark Hill was deposited at a palaeolatitude of $c .60^{\circ} \mathrm{S}$ (Veevers 2000).

\section{Marburg Subgroup}

Several bennettitalean 'flowers', receptacle fragments and isolated bracts from Durikai in southeast Queensland derive from the Marburg Subgroup exposed in a small outlier of the Clarence-Moreton Basin perched on mid-Palaeozoic strata of the Texas Block (Exon 1976; Fig. 1). Although the 
Marburg Subgroup is divided into two units (the Gatton Sandstone and overlying Koukandowie Formation) in the eastern part of the basin (Wells and O'Brien 1994; Goscombe and Coxhead 1995), these subdivisions are not recognisable along the basin's western margin. In that area, the Marburg Subgroup is represented by an undifferentiated succession of mature quartzose sandstones and shales deposited by mixed sinuosity streams flowing generally in a northerly direction (Cranfield et al. 1975; O'Brien and Wells 1994). Hence, strata within the outlier at Durikai cannot be correlated precisely with formal subunits of the Marburg Subgroup in the eastern Clarence-Moreton Basin. The Durikai flora is heavily dominated by bennettitalean foliage, but the assemblage remains largely undescribed (Cook and Rozefelds 2015). The only previous studies of the Durikai fossil plant assemblage were brief reports on the presence of Otozamites, Sagenopteris, Dictyophyllum, Phlebopteris and Equisetites (Tenison Woods 1884; Feistmantel 1890; Etheridge 1888, 1890; Walkom 1921; Hill et al. 1966; Turner et al. 2009; Gould 1968), a short overview of the flora (Gould 1971), a popular science summary (Rozefelds and Sobbe 1983) and the description of a putative Caytonia (but probable Coniopteris) fertile organ (Clifford 1998). Beds rich in conifer, fern, caytonialean and umkomasialean leaves and invertebrate traces at Inverleigh (around $25 \mathrm{~km}$ from Durikai) near the western margin of the Clarence-Moreton Basin were tentatively assigned to the Gatton Sandstone by Jansson et al. (2008a, b) and McLoughlin et al. (2014), but the fossil suite from those deposits differs markedly in composition from the nearby Durikai assemblage. The Marburg Subgroup has been assigned a Pliensbachian-Aalenian age based on spore-pollen assemblages (Burger 1994). The Durikai deposits were laid down at a palaeolatitude of c. $60^{\circ} \mathrm{S}$ (Veevers 2000).

\section{Injune Creek Group}

A specimen from Bymount Station, Eumamurrin, approximately $50 \mathrm{~km}$ south-southeast of Injune in the Surat Basin, southern Queensland (Fig. 1), derives from undifferentiated strata of the Injune Creek Group. However, exposures along strike immediately to the west of this site are more precisely assigned to the Birkhead Formation representing the middle subunit of the Injune Creek Group (Exon 1976). The fossiliferous rocks at Eumamurrin are strongly silicified mudstones and occur within a succession of carbonaceous mudstones, siltstones, lithic sandstones and coals deposited within deltaic and low-energy, high-sinuosity, fluvial systems. Few palaeobotanical studies have targeted the Injune Creek Group (Hill et al. 1966; Gould 1968; Tidwell and Rozefelds 1990), but the correlative Walloon Coal Measures in the eastern part of the Surat and adjoining Clarence-Moreton basins have yielded a rich and diverse flora (Gould 1974, 1980; Rigby 1978; McLoughlin and Drinnan 1995). Palynostratigraphic studies of the Injune Creek Group have assigned the unit an Aalenian-Bajocian (Middle Jurassic) age (Burger 1968). The fossiliferous deposits at Eumamurrin accumulated at a palaeolatitude of $60^{\circ}-70^{\circ} \mathrm{S}$ (Veevers 2000).

\section{Lees Sandstone}

A single reproductive organ is available from the Lees Sandstone exposed $3.2 \mathrm{~km}$ northwest of Old Bauhinia Downs Homestead, in the Carpentaria Basin of the eastern Northern Territory (White 1961; Fig. 1). The Lees Sandstone represents the deposits of a braided fluvial system and consists mainly of massive to cross-bedded quartzose sandstones together with minor conglomerates and siltstones. The unit is typically assigned an Early Cretaceous (BerriasianHauterivian) age (Skwarko 1966), although the basal beds of the unit may locally have been deposited in the Jurassic (Day et al. 1983). The formation hosts a rich impression flora dominated by bennettitalean and conifer leaves (White 1961, 1986). Permineralized gymnosperm wood is sparsely distributed within the unit (White 1961); the sharply defined growth rings in the wood attesting to strongly seasonal conditions experienced at a palaeolatitude of $c .60^{\circ} \mathrm{S}$ (Veevers 2000).

\section{Styx Coal Measures}

Two dispersed bracts of bennettitalean reproductive organs (GSQF1238, GSQF1242) are available in core samples from the Styx No. 4 Government stratigraphic bore (Fig. 1) at depths of $49.68 \mathrm{~m}(163 \mathrm{ft})$ and $50.29 \mathrm{~m}$ (165 ft). The fossils derive from the Styx Coal Measures, which represent the only formally defined unit within the Styx Basin of east-central Queensland. The Styx Coal Measures are poorly exposed but stratigraphic drilling indicates that they represent a succession of quartzose to lithic and locally pebbly sandstones, conglomerates, siltstones, carbonaceous shales and coals (Svenson and Taylor 1975). Two major facies associations are represented within this unit: a shallow marine shelf to shoreline association and a delta plain association (Fielding 1992). The discontinuous coals and associated plant-bearing shales occur within the latter facies association developed in the upper part of the unit. Only a single significant palaeobotanical study has been undertaken on the Styx Coal Measures thus far (Walkom 1919). That study identified a flora containing several conifers and angiosperms, but a large proportion of the fossil flora including ferns, Bennettitales and Pentoxylales was never described. The unit has been assigned an Albian age based on palynostratigraphic studies (Dettmann et al. 1992). The Styx Coal Measures accumulated at palaeolatitudes of $c .60^{\circ}-65^{\circ} \mathrm{S}$ (Veevers 2000). 


\section{Systematic palaeontology}

We describe the species of each genus in stratigraphic order to facilitate discussion of their biostratigraphical, palaeogeographical and palaeoecological significance. Numerous cladistic analyses over the past three decades have shown that Cycadales and Bennettitales do not have a close phylogenetic relationship (Crane 1985; Nixon et al. 1994; Hilton and Bateman 2006; Doyle 2006). Cycads are typically positioned basal to all extant (and post-Carboniferous fossil) seed plants, whereas Bennettitales possess many derived characters, and in most analyses based on morphological data, these are found to cluster with Gnetales and angiosperms as part of an anthophyte clade. On this basis, we refrain from grouping Bennettitales and Cycadales within a single class and refer them respectively to Bennettitopsida and Cycadopsida following the systematic approach of Anderson et al. (2007).

Class Bennettopsida Engler, 1897

Order Bennettitales Engler, 1892

Family Williamsoniaceae Carruthers, 1870

Genus Williamsonia Carruthers, 1870 emend. Harris, 1969

Type species: non designatus (according to Farr and Zijlstra 1996+); Williamsonia gigas (Lindley and Hutton) Carruthers, 1870 (according to Harris 1969 and Andrews 1970); Bajocian; Yorkshire, UK.

Remarks: The type species and the precise application of the name Williamsonia are matters of some ambiguity. Andrews (1970) and later scholars, such as Pott and Axsmith (2015), regarded W. gigas as the type species by following Harris (1969). Williamsonia gigas was the first species of the genus published by Carruthers (1870). Harris (1969) stated that Carruthers established the genus for all the organs that he interpreted to belong to a single plant. Carruthers based his view on a plant that was earlier restored from separate organs by Yates (1847) and Williamson (1847) as Zamia gigas. Although Harris (1969) accepted Carruthers' interpretation, he restricted the use of Williamsonia to ovuliferous bennettitalean flowers alone. This accords with discussions on the application of the generic name in subsequent early systematic treatments published by Saporta (1891) and Nathorst $(1909,1913)$. However, the original diagnosis provided by Carruthers (1870) included only characters of the foliage that had been assigned originally to Zamia/Zamites gigas (Lindley and Hutton 1835). Harris (1969) restricted the name $W$. gigas to the ovuliferous flowers while retaining the foliage under Zamites gigas. Should these organs be found in attachment, the naming of the whole plant may be a matter of debate based on the provisions of the Code (McNeill et al. 2012; see, e.g. Pott (2014a) for discussion concerning the erection of fossil taxa for whole-plant concepts). Nevertheless, Harris'
(1969) technical use of different names for separate organs has been widely adopted. He provided emended diagnoses for both ovuliferous and foliar organs and we follow his practice here in referring isolated ovuliferous flowers to Williamsonia.

Williamsonia eskensis sp. nov. (Fig. 2a)

2010 Bennettitalean 'flower'; McLoughlin and Pott, p. 6, fig. 3.

Holotype: QMF58844; here designated; here figured in Fig. 2a.

Type locality, unit and age: Paddys Gully, near the Coominya turnoff from the Brisbane Valley Highway near Esk, southeast Queensland (Fig. 1); Esk Formation; Anisian-Ladinian.

Etymology: After the type formation.

Diagnosis: Small Williamsonia composed of a whorl of c. 20 basally fused linear, entire-margined bracts arranged in an oblong perianth with short longitudinally aligned hairs on the adaxial surface; base abruptly truncate.

Description: The single specimen is an intact detached flower preserved as an impression in yellow mudstone. The perianth consists of at least one whorl of c. 20 bracts inserted on the remnants of a 4-mm-wide stalk. Bracts appear fused at the base but are free for most of their length and are tightly arranged to form an oblong cup $17 \mathrm{~mm}$ in diameter. Basal parts of the bracts are sharply arched to give the flower a markedly truncate base. Individual bracts are linear, $c .1 \mathrm{~mm}$ wide at the base, expanding to a maximum of $3 \mathrm{~mm}$ wide $1.5-2.0 \mathrm{~mm}$ above the base, and then tapering distally. The distal portions of all bracts are concealed but they reach at least $28 \mathrm{~mm}$ long. Bract margins are entire but the adaxial surfaces bear numerous, weak, short, longitudinal striae that appear to represent short hairs. Details of the ovuliferous receptacle are not available.

Remarks: This Middle Triassic specimen appears to be the oldest bennettitalean reproductive structure yet recorded. It differs from congeneric forms by the combination of its small gross size, narrow, mostly entire-margined bracts that are slightly expanded above the base, and the weakly striate (hirsute) adaxial surface of the bracts. At least one species of Pterophyllum occurs in the Esk Formation flora (Walkom 1924; Hill et al. 1965) and is potentially affiliated with this reproductive structure. The $W$. eskensis specimen is small compared with the few other known early (pre-Norian) bennettitalean (williamsoniacean) reproductive structures (Pott et al. 2010a). The earliest reproductive structures elsewhere with similar dimensions to $W$. eskensis are reported from the Rhaetian-Hettangian (Nathorst 1880, $1888,1902)$. In particular, the specimen of Wielandiella angustifolia from the Hettangian Höör Sandstone of southern Sweden (Nathorst 1880, Pott 2014a) is strikingly similar in dimensions and outline to $W$. eskensis but has bracts with distinct transverse striae. 


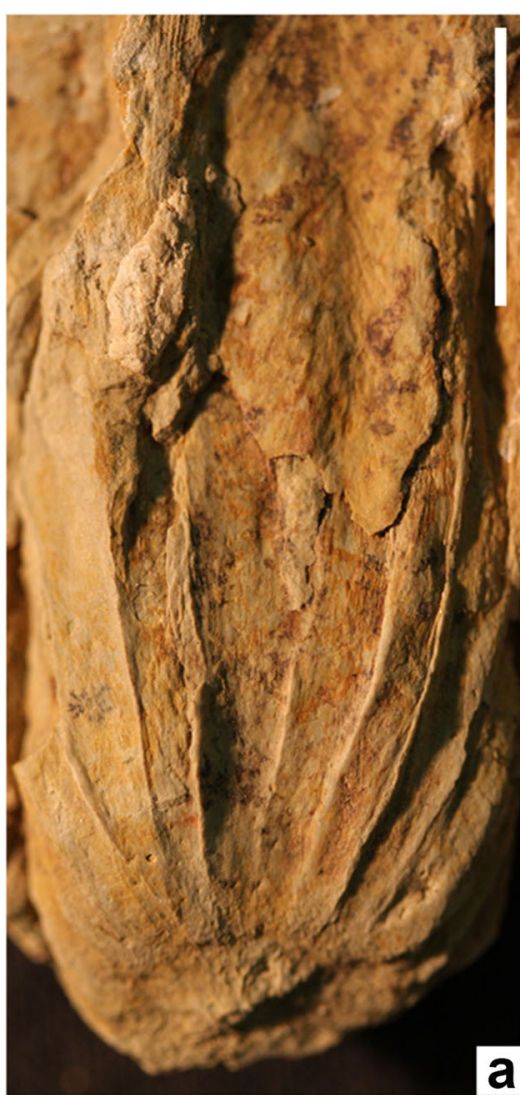

Fig. 2 Triassic bennettitalean reproductive structures from Australia. a Williamsonia eskensis sp. nov., QMF58844 (holotype), Paddys Gully, near the Coominya turnoff from the Brisbane Valley Highway near Esk, southeast Queensland, Esk Formation (Anisian-Ladinian). b

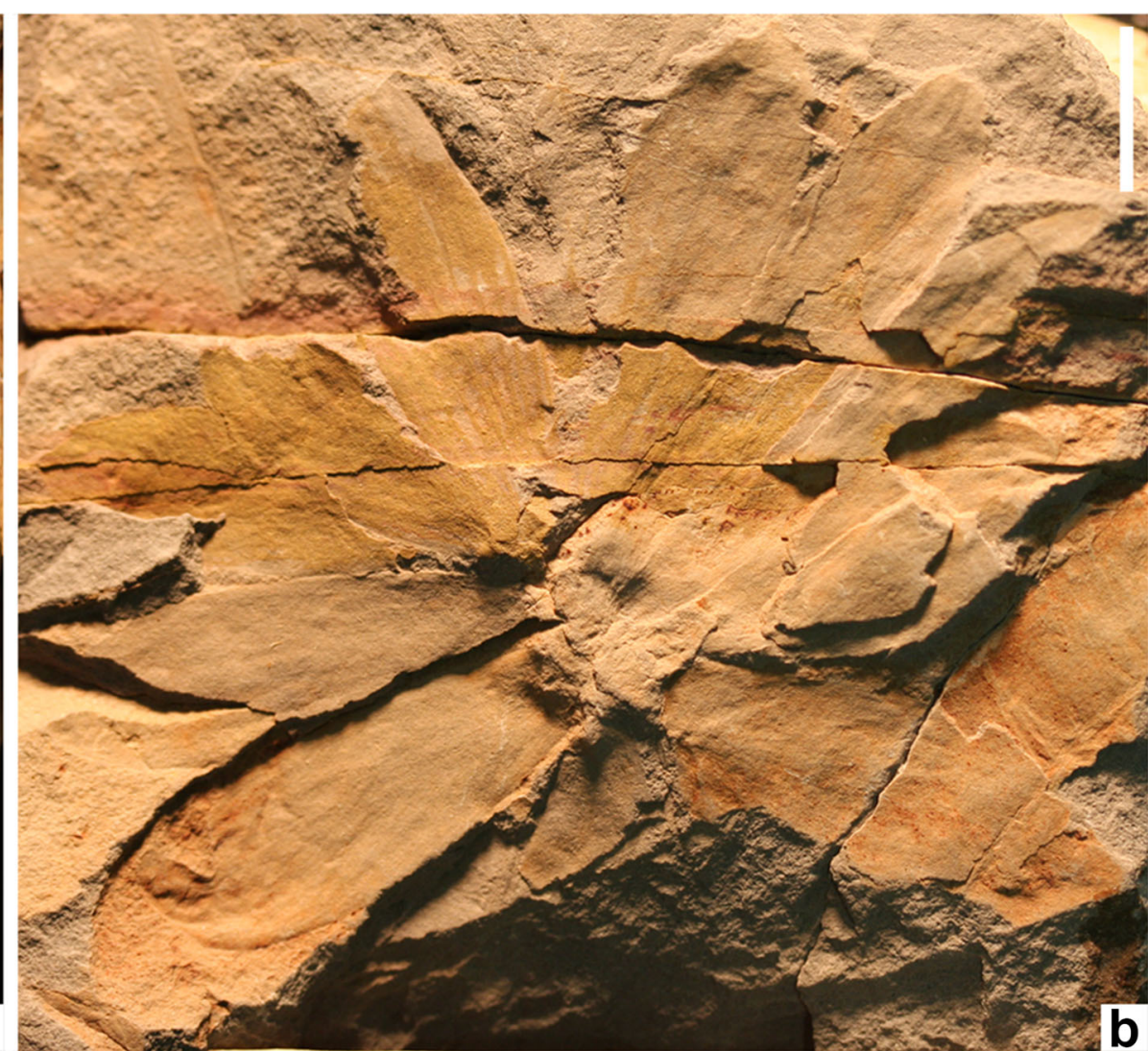

Williamsonia ipsvicensis sp. nov., UQF16337 (holotype), Denmark Hill, Ipswich Basin, southeast Queensland, Blackstone Formation (Carnian or earliest Norian). Scale bars $=10 \mathrm{~mm}$

same locality, but we were unable to locate this fossil. Few key morphological details are discernible from the available specimen, but we assign it to a new species based on its distinctive oblanceolate, entire-margined bracts, with broadly rounded apices and distinctive sub-parallel venation. It has superficial similarities to Williamsonia carruthersii (Seward) Seward, 1913, but the latter differs by its lanceolate and more acutely pointed bract apices (Watson and Sincock 1992).

We hold some reservations about assignment of this specimen to Williamsonia, since details of a central receptacle are not preserved and the bracts bear certain similarities in shape and dichotomous venation to some leaves of Heidiphyllum elongatum (Retallack 1981). Moreover, the phyllotaxy of the presumed perianth is ambiguous and, given that the bases of several bracts are at different levels in the rock, it is possible that the bracts are arranged in a tight helix rather than in whorls. Thus, it is conceivable that, alternatively, the specimen represents a shoot tip of $H$. elongatum preserved in plan view with a tight helix of radiating unexpanded (immature) leaves.

Williamsonia durikaiensis sp. nov. (Figs. 3a, e, j-1 and 4a-f) 


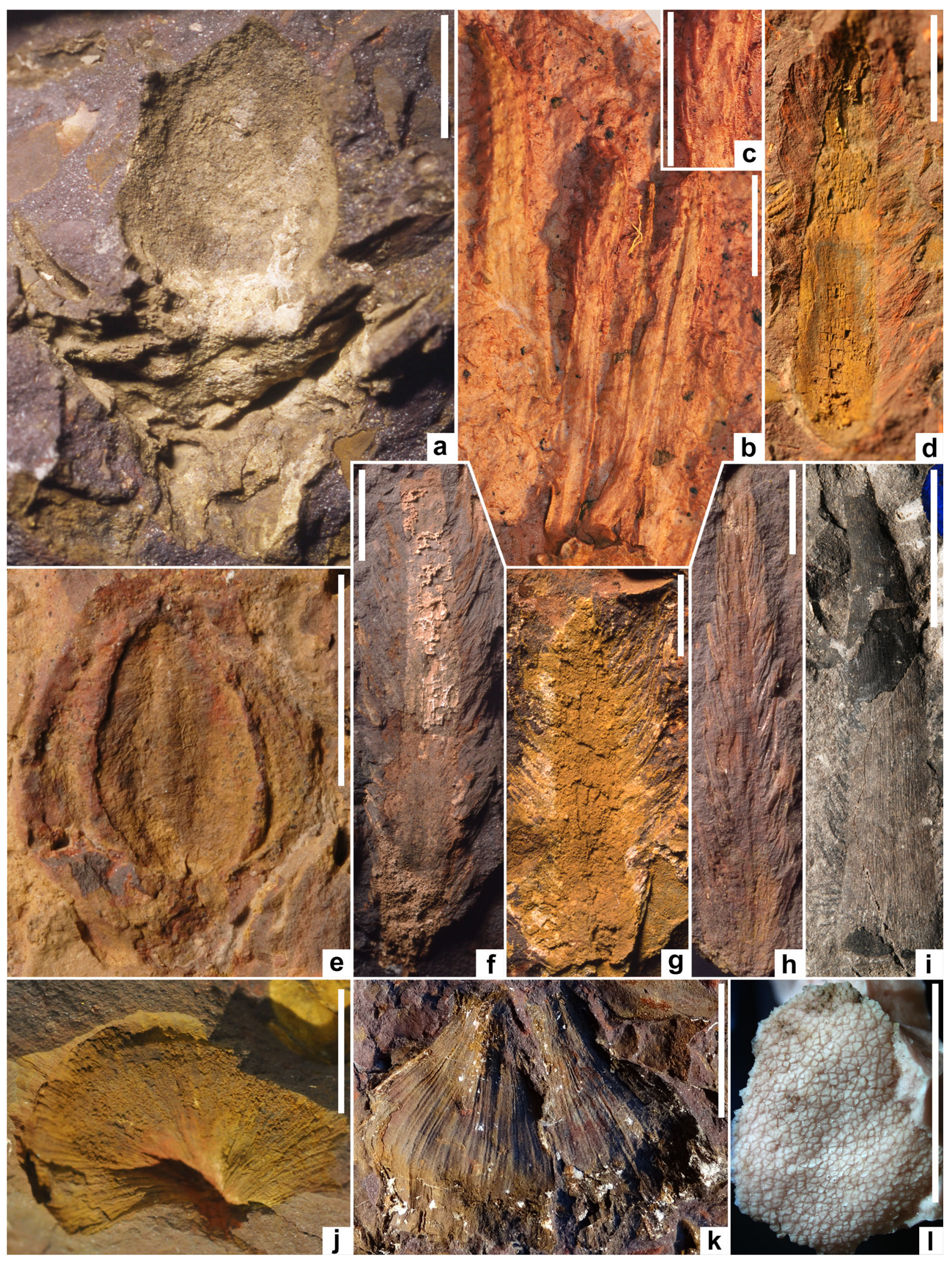


Fig. 3 Triassic and Cretaceous bennettitalean reproductive structures from Australia. a Williamsonia durikaiensis sp. nov., QMF55954 (holotype), mould of gynoecium attached to stalk terminus. b Cycadolepis ferrugineus sp. nov., QMF58027, several sparsely hirsute slender bracts. c Enlargement of marginal hairs in b. d C. ferrugineus sp. nov., QMF12698, bract with marginal hairs. e W. durikaiensis sp. nov., QMF54909, impression of small gynoecium flanked by appressed bracts. f C. ferrugineus sp. nov., QMF55916, bract with marginal hairs. g C. ferrugineus sp. nov., NRM S081428, broad bract with marginal hairs. h C. ferrugineus sp. nov., QMF56037 (holotype), slender bract with marginal hairs. i Cycadolepis sp., GSQF1242, narrowly triangular bract with fine marginal hairs. $\mathbf{j}$ Transverse fracture through gynoecium of W. durikaiensis sp. nov. showing radiating ovules/interseminal scales. $\mathbf{k}$ Two immature $W$. durikaiensis sp. nov. 'flowers' with tightly appressed bracts, QMF58028 (left) and QMF58029 (right). I NRMS089785, dental polymer cast of $W$. durikaiensis sp. nov. gynoecium fragment (QMF55936) showing polygonal termini of ovules and interseminal scales. a-h, j-l From outcrop $300 \mathrm{~m}$ east of Durikai Siding, $35 \mathrm{~km}$ west of Warwick, southern Queensland, undifferentiated Marburg Subgroup (Pliensbachian-Aalenian); i From 50.29 m in Styx No. 4 Government stratigraphic bore, Styx Basin, east-central Queensland, Styx Coal Measures (Albian). Scale bars $=10 \mathrm{~mm}$

Holotype: QMF55954; here designated; here figured in Fig. 3a.

Additional material: NRMS089785, QMF55936, QMF58026, QMF54909, QMF58028, QMF58029.

Type locality, unit and age: Outcrop $300 \mathrm{~m}$ east of Durikai Siding, $35 \mathrm{~km}$ west of Warwick, southern Queensland (Fig. 1); undifferentiated Marburg Subgroup; PliensbachianAalenian.

Etymology: After the type formation.

Diagnosis: Small Williamsonia with an ovoid receptacle surrounded by an inner whorl of slender lanceolate bracts; outer whorls of bracts stout with possibly hirsute margins. Receptacle terminal on branch. Immature flowers with tightly appressed and laterally abutting slender bracts forming a pyriform sheath around receptacle.

Description: The species is represented by rather poorly preserved impressions of ovuliferous receptacle fragments, a whole detached ovuliferous organ, two immature flowers and an ovuliferous organ attached terminally to a bractbearing axis. The flowers are $12-30 \mathrm{~mm}$ long and $7.5-$ $35 \mathrm{~mm}$ wide; gynoecium reaching $25 \mathrm{~mm}$ wide. In QMF54909 (Fig. 3e), lanceolate bracts up to $18 \mathrm{~mm}$ long emerge from the base of the receptacle and are tightly appressed to the gynoecium surface and extend at least to its apex. This specimen may represent an immature or unexpanded flower. In the largest specimen (QMF55954: Fig. 3a), the flanking bracts are splayed at about $60^{\circ}$ to the receptacle axis. Several tight helices of robust bracts emerge from the axis immediately below the receptacle in this specimen but their morphologies are difficult to resolve owing to poor preservation. The axes supporting the receptacles are 4.5-9.0 mm thick. Two small specimens (QMF58028 and QMF58029: Fig. 3k) represent immature (unopened) flowers with tightly appressed and laterally contiguous, slender, unornamented or sparsely hirsute bracts that extend above the receptacle to form a tube-like apex of a pyriform sheath. Cross-sections of receptacles reveal tightly bound slender prismatic ovules and interseminal scales (Fig. 3j). Impressions of the receptacle surface reveal polygonal apices of interseminal scales surrounding ovule micropyles (Figs. 31 and 4a). Micropyles are surrounded by four to seven interseminal scales (generally six) that are typically triangular in cross section with a truncate or slightly pyramidal apex (Fig. 4b-d). Interseminal scales have inflated epidermal cells giving the apices a rugose texture (Fig. 4f). Micropyles emerge as short tubes slightly above the level of the adjacent interseminal scale apices (Fig. 4e, f).

Remarks: Although several specimens are available, the indifferent preservational details of the receptacle and perianth bracts impede close comparisons with other taxa. The distribution of micropylar tubes suggests that ovules were slightly more densely spaced in $W$. durikaiensis compared with Williamsonia harrisiana from the Early Cretaceous of India (Bose 1968). The density of ovules and extension of the micropylar tubes is more or less the same as in European Williamsonia and Wielandiella specimens illustrated by Crane and Herendeen (2009) and Pott (2014a), but there are differences between all forms in the shape and elevation of the interseminal scale apices. Williamsonia pusilla Halle, 1913 from Lower Jurassic strata of Hope Bay, Antarctica (Rees and Cleal 2004), is represented only by the cross section of a gynoecium. The gynoecium width is markedly smaller (10 $\mathrm{mm}$ wide) than that of mature $W$. durikaiensis (18$25 \mathrm{~mm}$ wide) and there are few additional characters that can be compared (Gee 1989).

The co-preservation of $W$. durikaiensis flowers and detached Cycadolepis ferrugineus sp. nov. bracts at Durikai suggests that these may belong to the same plant. Bennettitalean foliage is extremely abundant at Durikai, constituting over $75 \%$ of the assemblage, but it has not yet been described in detail. At least two morphotypes attributable to Otozamites are present (Feistmantel 1890; Etheridge 1888, 1890; Walkom 1921; Gould 1971), but one (illustrated by Hill et al. 1966 pl. J VI.2-4 as Otozamites feistmanteli) vastly outnumbers the other and is most probably affiliated with $W$. durikaiensis.

\section{Williamsonia sp. (Fig. 5)}

Material: Two unregistered specimens (Australian Museum collections).

Locality, unit and age: Lune River gemfield, Tasmania; unnamed package of silicified siltstones, volcanolithic sandstones, mudstones and silicified tuff below andesitic-basaltic volcanics; probably Toarcian based on detrital zircon populations from the sandstones (Bromfield et al. 2007).

Remarks: Two permineralized ovuliferous organs (one external surface figured here: Fig. 5) with well-preserved 

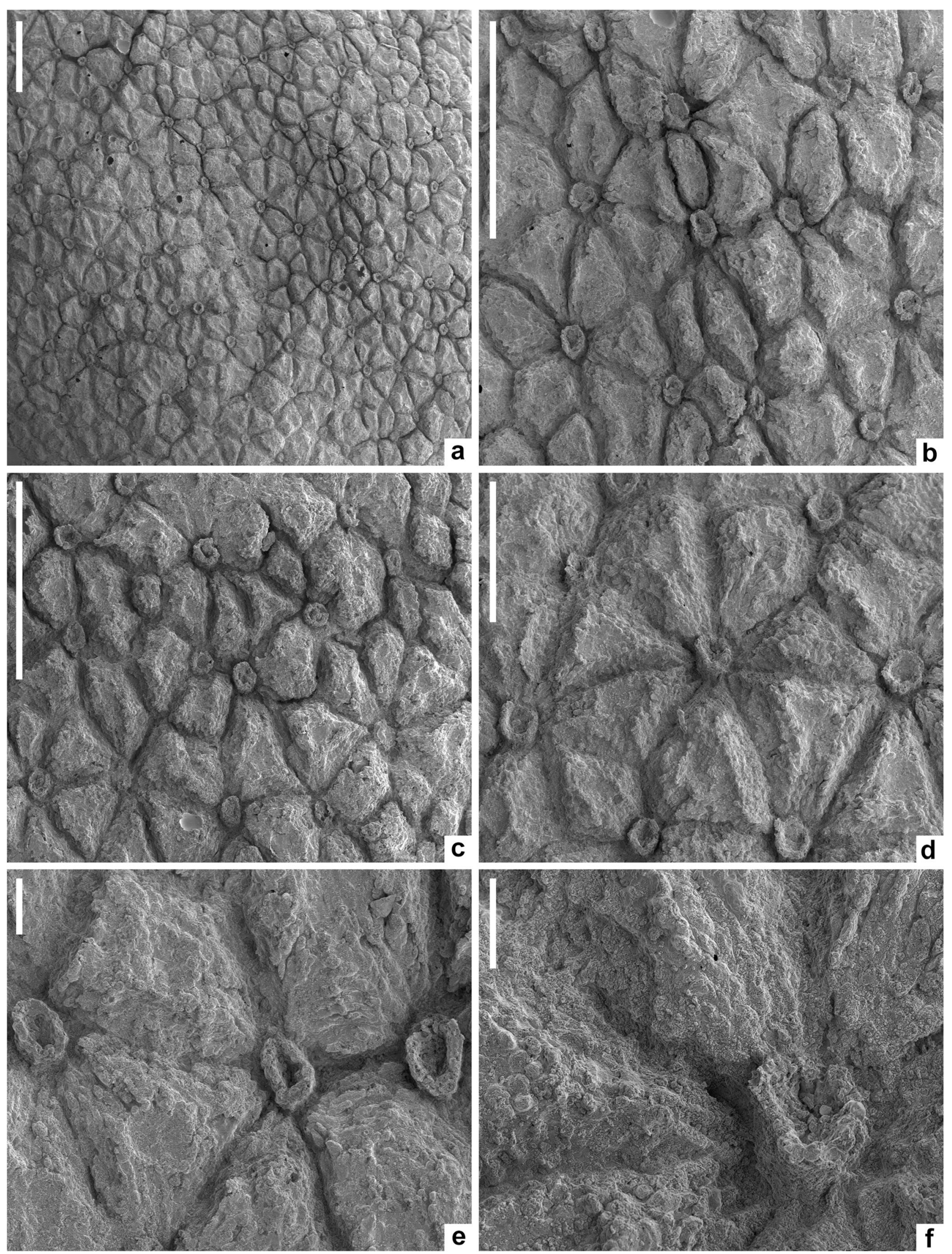
Fig. 4 Scanning electron micrographs of a dental polymer cast of the gynoecium surface of Williamsonia durikaiensis sp. nov., NRMS089785 (dental polymer cast of QMF55936). a arrangement of ovules and interseminal scales. $\mathbf{b}, \mathbf{c}$ variation in the arrangement of interseminal scales around ovules. d enlargement showing the truncate apices of interseminal scales. e enlargement showing the short tubular micropylar extensions. f enlargement showing inflated epidermal cells on interseminal scale apices and the ovule micropyle. Specimen from outcrop $300 \mathrm{~m}$ east of Durikai Siding, $35 \mathrm{~km}$ west of Warwick, southern Queensland, undifferentiated Marburg Subgroup (PliensbachianAalenian). Scale bars for $\mathbf{a}-\mathbf{c}=1 \mathrm{~mm} ; \mathbf{d}=500 \mu \mathrm{m} ; \mathbf{e}, \mathbf{f}=100 \mu \mathrm{m}$

anatomical details of the axis, receptacle, seeds and interseminal scales are known from this deposit. One of these exquisitely preserved specimens (Fig. 5) was illustrated in a popular science publication but never formally described (White 1991, pp. 105-106). Apart from their gross dimensions, the Tasmanian permineralized specimens cannot be readily compared with the other species described here, because the former lack details of the perianth. Comprehensive descriptions of these specimens with excellent anatomical preservation will be the topic of a separate paper.

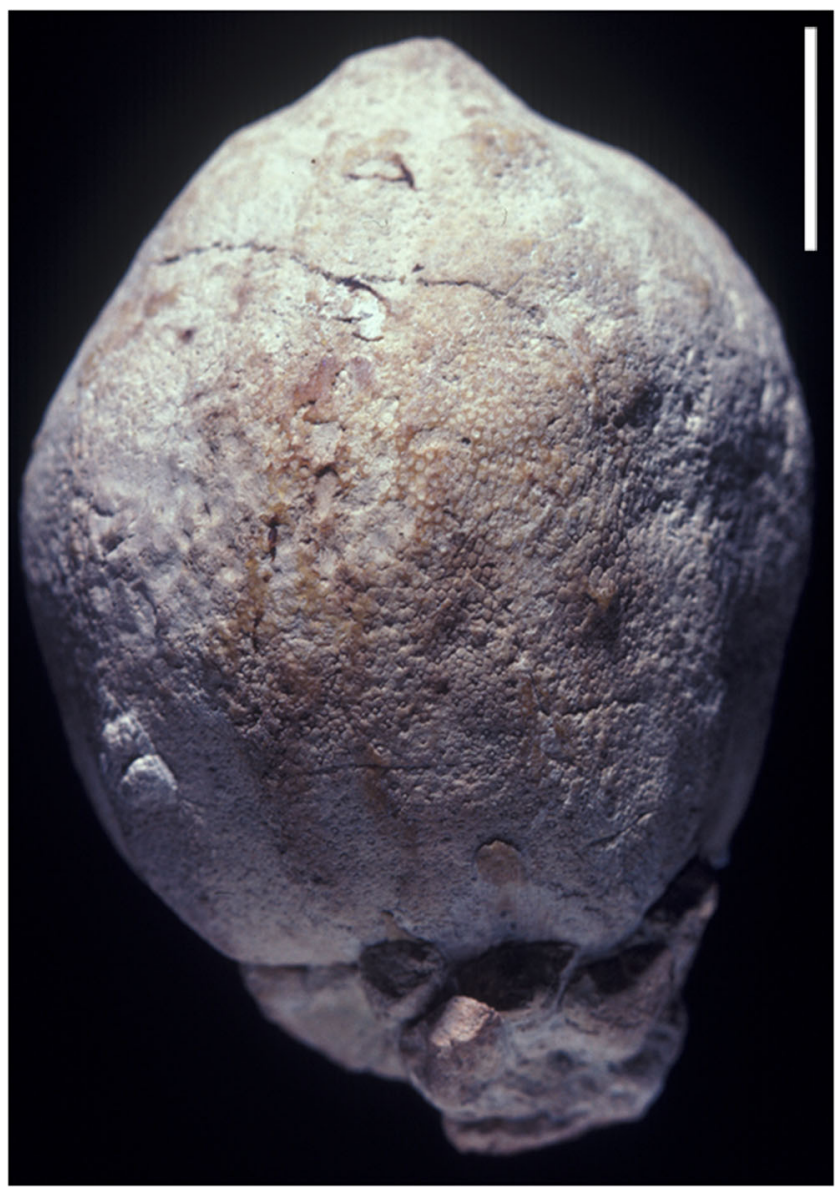

Fig. 5 External surface of a permineralized Williamsonia sp. gynoecium from Upper Jurassic deposits of Lune River, Tasmania. Unregistered Australian Museum specimen. Scale bar $=10 \mathrm{~mm}$
Williamsonia rugosa $\mathrm{sp}$. nov. (Fig. 6a-c)

1966 Williamsonia sp.; Hill et al., p. j14, pl. J VII, fig. 5. 2015 female cone of Williamsonia; Cook and Rozefelds, $\mathrm{p}$. 117, fig. 2.

Holotype: UQF10489; here designated; here illustrated in Fig. 6a-c.

Type locality, unit and age: Bymount Station, Eumamurrin near Injune, southern Queensland (Fig. 1); undifferentiated Injune Creek Group; Aalenian-Bajocian.

Etymology: Latin: rugosus - wrinkled; after the coarsely wrinkled texture of the abaxial surface of the perianth bracts. Diagnosis: Small Williamsonia incorporating several helices of longitudinally arched, slender, linear bracts with coarse transverse wrinkles, attached by their broad base and tapering consistently to acute apex.

Description: The single available specimen is an intact detached flower preserved as a silica replacement in silicified volcanigenic siltstone (Fig. 6a). The flower is $25 \mathrm{~mm}$ long and $21 \mathrm{~mm}$ wide at its greatest expansion. The perianth consists of at least two tight whorls of bracts, each whorl incorporating an estimated 12 bracts (only half the perianth is exposed on the slab surface). The stalk attachment is concealed but each bract appears to be free along its lateral margins from its broad (up to $2.7 \mathrm{~mm}$ wide) base. Bracts taper consistently from the base to their acutely pointed apex. Bracts are longitudinally arched to form a strongly convex abaxial surface (presumably grooved or concave on the adaxial surface). Bracts reach $25 \mathrm{~mm}$ long, those in the outermost ring appear to be slightly shorter (c. $16 \mathrm{~mm}$ long). The bract margins are entire. The bract abaxial surface bears numerous transverse wrinkles and striae (Fig. 6b). Ridges of the wrinkles are up to $0.3 \mathrm{~mm}$ wide. Small irregular knobs or bracteoles are positioned around the base of the bracts (Fig. 6c). Details of the receptacle are not available. Remarks: This species is primarily differentiated from others in the genus by its small size and distinctive coarse transversely wrinkled bracts. The basal knob-like features may represent broken bract bases or short bracteoles projecting from the supporting axis. An undescribed Otozamites species is abundantly co-preserved at the type locality (Ptilophyllum pecten of Hill et al. (1966), pl. J V, figs. 5-7; McLoughlin et al. 2015, fig. 4h) and is the probable foliar affiliate of this reproductive structure. Among the several ovuliferous Williamsonia-like flowers described by Pott et al. (2015) from the Callovian-Oxfordian of northeastern China are some that strongly resemble $W$. rugosa in their dimensions and arched bracts covered with transverse wrinkles. Those Chinese specimens have been interpreted to belong to the plant producing hirsute Anomozamites-type foliage and attributed to Wielandiella villosa. No such foliage has been identified in the Middle Jurassic floras of eastern Australia. 

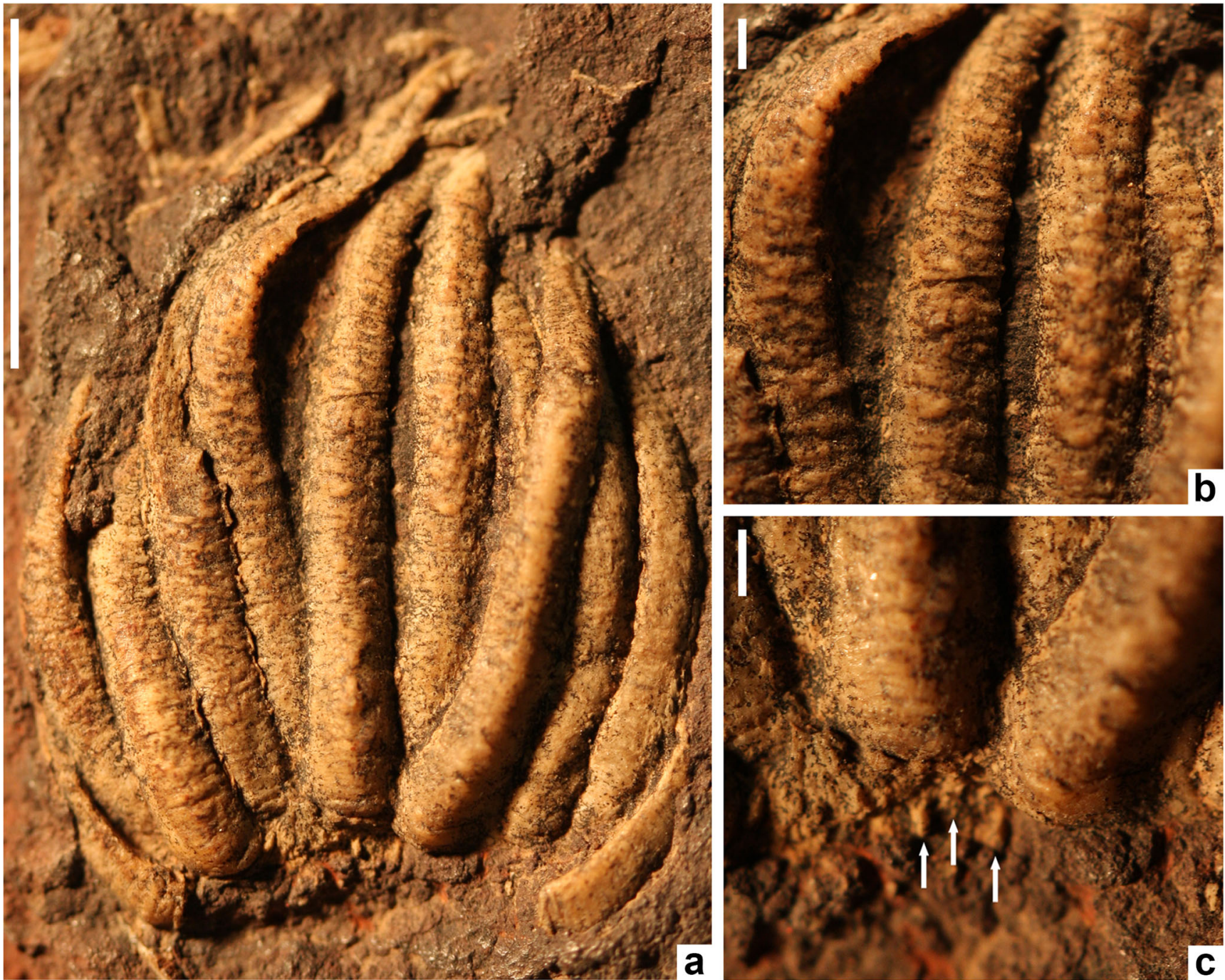

Fig. 6 Williamsonia rugosa sp. nov., UQF10489. a 'Flower' composed of several ranks of slender bracts. b Enlargement of bracts showing transversely wrinkled surface. c Base of flower showing knobs or

\section{Williamsonia gracilis sp. nov. (Fig. 7a-d).}

Holotype: GA F21889; here designated; here illustrated in Fig. $7 \mathrm{a}-\mathrm{d}$.

Type locality, unit and age: Locality TT32 of White (1961), $3.2 \mathrm{~km}$ northwest of old Bauhinia Downs Homestead, Northern Territory (Fig. 1); Lees Sandstone; BerriasianHauterivian.

Etymology: Latin: gracilis—slender; after the narrow, gracile nature of the bracts.

Diagnosis: Moderate-sized, globose Williamsonia with uniformly narrow, linear, entire-margined, basally fused bracts.

Description: The single available specimen is an intact detached flower preserved as a closed perianth impression enveloping a core of sandy sediment. The perianth consists of multiple whorls of bracts evidenced by several layers of fused discs surrounding the 9-mm-wide cavity left by the decay of the bracteoles (arrowed); Bymount Station, near Eumamurrin, Injune, southern Queensland, undifferentiated Injune Creek Group (AalenianBajocian). Scale bars for $\mathbf{a}=10 \mathrm{~mm} ; \mathbf{b}, \mathbf{c}=1 \mathrm{~mm}$

supporting stalk and receptacle (Fig. 7a, b). Only the impressions of the outer whorl of bracts are clearly evident (Fig. 7c, d). This ring incorporates at least 20 bracts that are consistently arched along their length to form a globose flower. The entire structure is $47 \mathrm{~mm}$ in transverse diameter and $46 \mathrm{~mm}$ in longitudinal diameter. The bracts appear to be fused basally into a narrow disc forming what Nathorst (1902) identified as the 'palisade ring' (but see Pott 2014a for the use of this term). Otherwise, the bracts are mostly free and maintain a constant width of $2.5 \mathrm{~mm}$. Apices of the bracts are weakly pointed. The margins are entire, and the adaxial surface of each bract is flat and smooth. Bracts reach c. $50 \mathrm{~mm}$ long (following their curvature). Remarks: This species is differentiated by its moderate size and large number of unornamented bracts of consistent width in the outermost whorl. It differs from most European and Indian Mesozoic species by its very slender bracts (cf. Watson and Sincock 1992; Bose 1968; Sharma 1977). 

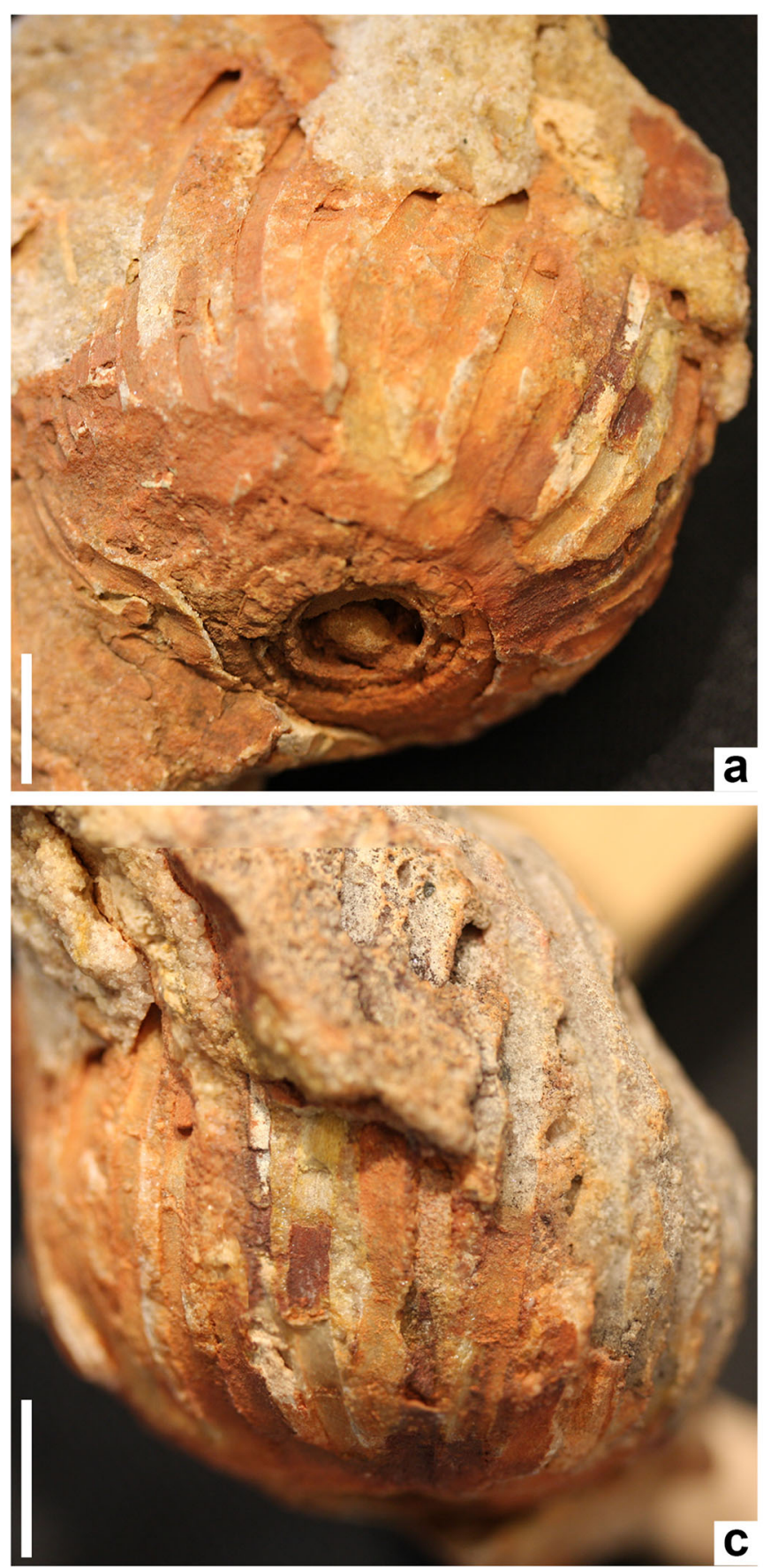

Fig. 7 Williamsonia gracilis sp. nov., GA F21889. a, b Oblique ventral views showing basal fusion of bracts in several ranks. c, $\mathbf{d}$ Lateral and oblique dorsal views of 'flower' showing strongly arched slender bracts;

Williamsonia latecostata Semaka emend. Popa, 2014, from the Sinemurian of Romania, approaches $W$. gracilis in bract width but the former is typically a much larger (around twice as large) reproductive structure. Williamsonia sp. from the Upper Jurassic Latady Formation, Graham Land, Antarctica (Riley et al. 1997), is of similar dimensions to W. gracilis but has bracts that are more tapered throughout their length.
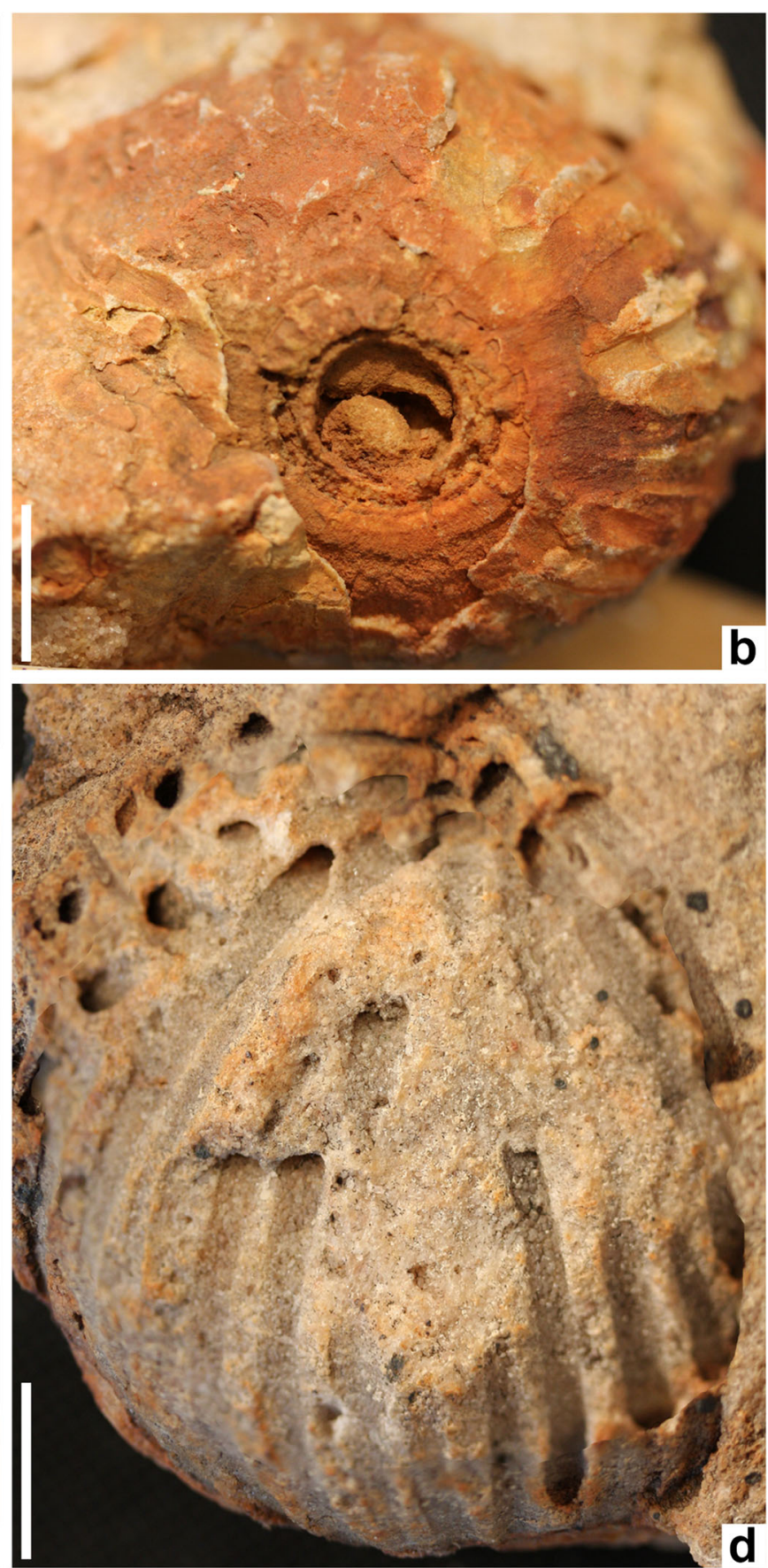

locality TT32 of White (1961), 3.2 km northwest of old Bauhinia Downs Homestead, Northern Territory; Lees Sandstone (BerriasianHauterivian). Scale bars $=10 \mathrm{~mm}$

Williamsonia gracilis is co-preserved with abundant leaves referable to Otozamites sp. cf. O. bengalensis, a leaf form widely reported from northern and Western Australia (White 1961; McLoughlin 1996; McLoughlin and Hill 1996; McLoughlin and Pott 2009; McLoughlin et al. 2010) and similar to forms from the Early Cretaceous of India (Bose and Kasat 1972). The absence of any other bennettitalean foliage in the strata at the 
type locality suggests that these foliar and reproductive organs are biologically affiliated.

Genus Cycadolepis Saporta, 1875 emend. Harris, 1953

Type species: Non designatus (Farr and Zijlstra 1996+; putatively Cycadolepis villosa Saporta, 1875; Jurassic; Ain, France.

Remarks: The type species of Cycadolepis is equivocal. Harris $(1953,1969)$ regarded C. villosa, the first species described by Saporta (1875), as the type, but restricted the generic diagnosis to include only scale leaves with bennettitalean stomatal morphology. However, this makes the type species technically problematic because epidermal details are not available for Saporta's (1875) material, and morphologically similar scale leaves with cycadalean-type polycytic stomata are assigned to Deltolepis (Harris 1969).

Cycadolepis ferrugineus sp. nov. (Fig. 3b-d, $\mathrm{f}-\mathrm{h}$ ).

Holotype: QMF56037; here designated; here figured in Fig. 2h.

Additional material: QMF12698, QMF55916, QMF58027, NRM S081428.

Etymology: Latin ferrugineus - the colour of iron rust.

Locality, unit and age: From outcrop 300 m east of Durikai Siding, $35 \mathrm{~km}$ west of Warwick, southern Queensland (Fig. 1); undifferentiated Marburg Subgroup; PliensbachianAalenian.

Description: The impressions of several lanceolate bracts are available. The bracts are $36-60 \mathrm{~mm}$ long with a central lamina 4.0-8.5 mm wide, the widest point being at or just above the base. A fringe of densely spaced, $6-9 \mathrm{~mm}$ long, $<1.2 \mathrm{~mm}$ wide, linear to falcate, apically inclined spines or hairs line the lamina margins of most specimens (Fig. $3 \mathrm{~d}, \mathrm{f}-\mathrm{h}$ ). The hairs are acutely $\left(5^{\circ}-40^{\circ}\right)$ inserted on the lamina margin and are either straight or slightly falcate. Each hair appears to have a fine median groove or vein. A few bracts are markedly more slender and bear fewer marginal hairs (Fig. 3b, c) and may derive from the inner whorl of a perianth. The bract base is truncate and the apex acutely pointed. The lamina bears weak longitudinal striae and is either flat or gently concave about a longitudinal axis.

Remarks: This bract type is co-preserved with $W$. durikaiensis in the Marburg Subgroup, and it is possible that they belong to the same parent plant, although poor-preservation does not allow clear recognition of hairs on the perianth parts of the latter. As Harris $(1944,1969)$ noted, Cycadolepistype bracts commonly form the caducous involucrum of bennettitalean ovuliferous flowers, and the hairs or spines are borne only on the outer scales, whereas the inner scales of the same flower were glabrous. No microsporangia are evident on these bracts, so it is likely that they represent protective structures forming the outer perianth whorls of the Williamsonia flower and may have detached with floral maturity. Cycadolepis bracts from roughly coeval strata at Hope and Botany bays on the Antarctic Peninsula differ in being generally smaller (<38 mm long) and triangular (Halle 1913; Gee 1989) or ovate (Rees and Cleal 2004).

Cycadolepis sp. (Fig. 3i).

Material: GSQF1238, GSQF1242.

Locality, unit and age: Styx No. 4 Government stratigraphic bore (50.29 m depth), Styx Basin, east-central Queensland (Fig. 1); Styx Coal Measures; late Early Cretaceous (Albian). Description: The two available bracts of this taxon have an elongate triangular lamina, $31 \mathrm{~mm}$ long, $6.5 \mathrm{~mm}$ wide at the base, fringed by dense marginal falcate hairs up to $2.8 \mathrm{~mm}$ long and $<0.4 \mathrm{~mm}$ wide (Fig. 3i). Both the bract base and apex are slightly damaged but appear to be truncate and acutely pointed, respectively. A weakly defined keel is developed along the centre of the lamina, which is otherwise ornamented with fine longitudinal striae, and is gently concave about a longitudinal axis.

Remarks: This morphotype is differentiated from C. ferrugineus and other species by its finer marginal hairs, a weakly defined keel and more distinct longitudinal striae on the lamina. Apart from the fine surficial striae, the relatively even surface and thin remnants of coalified tissue on Cycadolepis sp. contrast with the rather rough surface texture and thick mineral infillings of the bract mesophyll on some specimens of $C$. ferrugineus. No complete bennettitalean flowers or leaves have been found in the Styx Coal Measures but bennettitalean foliage (Otozamites or Ptilophyllum species) occurs in coeval (Albian) strata (Burrum Coal Measures) in the neighbouring Maryborough Basin (Walkom 1919).

Order Fredlindiales Anderson and Anderson, 2003

Family Fredlindiaceae Anderson and Anderson, 2003

Genus Fredlindia Anderson and Anderson, 2003

Type species: Fredlindia fontifructus Anderson and Anderson, 2003; Carnian; Karoo Basin, South Africa.

Remarks: Fredlindia and its putative associated foliage Halleyoctenis (Anderson and Anderson 1989) are clearly allied to Bennettitales based on their minute, densely packed, prism-like ovules and brachyparacytic stomata. They differ in having multiple ovule-bearing receptacles borne in whorls on a central axis and in having only mildly sinuous anticlinal epidermal cell walls. On this basis, Anderson and Anderson (2003) erected the new family Fredlindiaceae and order Fredlindiales to accommodate Fredlindia and its affiliated organs. 
Fredlindia moretonensis Shirley, 1898 comb. nov. (Fig. 8a-j)

1898 Equisetides moretonensis Shirley 1898, Geol. Surv. Qd Bull. 7, p. 25, pl. XVIII, fig. 3. (basionym).

1947 Equisetites? sp.; Jones and de Jersey, p. 9, pl. 1, fig. 1; text-fig. 1.

1965 Neocalamites cf. carrerei (Zeiller) Halle, Hill et al., pl. TI, fig. 3.

2015 Neocalamites carrerii nodal diaphragm; Cook and Rozefelds, p. 85, fig. 2.

Holotype: QMF543; here designated; here illustrated as Fig. 8c.

Type locality, unit and age: Denmark Hill, Ipswich Basin, southeast Queensland; Blackstone Formation; Carnian or earliest Norian.

Additional material: AMF43500, QMF2503, QMF2505 (two specimens), QMF2506, QMF6012, UQF64190, UQF8115.

Diagnosis: Gynoecium more-or-less bilaterally symmetrical, circular, elliptical or obovate, borne on a stout to slender pedicel. Ovules and interseminal scales form a marginal rim around receptacle and possibly covering abaxial surface. Interseminal scales rod-shaped, prismatic; ovules $c$. four to five times the width of interseminal scales but otherwise similar in shape.

Description: All specimens represent isolated bilaterally symmetrical, dorsoventrally flattened, circular, elliptical or obovate gynoecia retaining ovules and interseminal scales only around the margins of the receptacle. The gynoecia are 9$20 \mathrm{~mm}$ long $\times 8-14 \mathrm{~mm}$ wide and are borne on a pedicel up to $11 \mathrm{~mm}$ long and $4 \mathrm{~mm}$ wide. The gynoecium was apparently thick (fleshy or leathery) and has been replaced in most specimens by a clay cast. Where the cast is removed, the adaxial surface is scabrate (Fig. 8a, b, d, e, h). The abaxial surface bears numerous fine $(<0.2 \mathrm{~mm}$ diameter) pits (Fig. $8 \mathrm{c}$, $f, j)$ that probably represent detachment points of ovules and interseminal scales. Ovules and interseminal scales are densely packed into rod-like prisms $3-5 \mathrm{~mm}$ long; ovules are somewhat swollen, reaching $1 \mathrm{~mm}$ wide, whereas interseminal scales are typically $<0.2 \mathrm{~mm}$ wide (Fig. $8 \mathrm{~g}, \mathrm{i}, \mathrm{j}$ ).

Remarks: Nine detached gynoecia are available. In each case, the ovules and interseminal scales are retained only around the gynoecium margin, and this flange might have acted to promote wind dispersal of those seeds retained on the gynoecium. This wing-like arrangement of marginal ovules and interseminal scales probably led previous workers to interpret these organs as equisetalean strobilar scars (Shirley 1898), strobili (Jones and de Jersey 1947) or nodal diaphragms (Hill et al. 1965; Cook and Rozefelds 2015). Detachment scars indicate that ovules and interseminal scales were originally present over the entire abaxial surface - a condition consistent with the only other known species in the genus, F. fontifructus, from the Carnian of the Karoo Basin, South
Africa (Anderson and Anderson 2003). The new species differs from the type species in having a lesser length/width ratio for the gynoecium, in many cases giving $F$. moretonensis a near-circular as opposed to oblanceolate shape. Anderson and Anderson (2003) interpreted all of the rod-like structures attached to the receptacle as slender ovules. However, we note significant variation in the widths of elements comprising the marginal wing-like structure and interpret these to be thick ovules separated by slender interseminal scales. This interpretation is consistent with the architecture of other bennettitopsid ovuliferous organs (Pott 2016). Given that most of the illustrated gynoecia of $F$. fontifructus are retained on a whorled, loosely cone-like structure, the ovules may be undeveloped and difficult to differentiate from interseminal scales in the holotype of that species. We note, however (Anderson and Anderson (2003), pl. 130, fig. 3, pl. 131, fig. 4), that some of the detached South African gynoecia show marked undulations around the margin that might represent alternating ovule and interseminal scale packages.

Apart from architectural similarities in the gynoecia, Anderson and Anderson (2003) considered Fredlindia to be of bennettitopsid alliance based on association of the ovuliferous organs with dispersed Halleyoctenis foliage, Weltrichia microsporangiate organs and Cycadolepis bracts in the Upper Triassic Molteno Formation, South Africa. Halleoctenis leaves are also known from the Middle to Late Triassic of the Esk Trough, Nymboida Coal Measures and Ipswich Basin in eastern Australia, strengthening the association between this foliage genus and Fredlindia (Anderson and Anderson 2003). Fredlindia also approaches Westersheimia pramelreuthensis from the Carnian of Lunz in its architecture (Kräusel 1949; Pott 2016) but these organs are distinguished by three main characters: (1) the gynoecia of $F$. fontifructus are arranged in whorls around a central axis, whereas in W. pramelreuthensis, they are opposite (pinnate) and there is no indication that they were arranged spirally; (2) gynoecia of W. pramelreuthensis appear to be completely covered with ovules and interseminal scales (radial symmetry), whereas those of $F$. fontifructus are interpreted to have a naked adaxial surface (bifacial organisation); (3) no interseminal scales were reported to be present in the original description of Fredlindia, whereas they are interspersed among the ovuliferous scales in Westersheimia. The last of these distinctions is questionable given the interpreted architecture of $F$. moretonensis herein.

\section{Discussion}

The oldest Bennettitales

A survey of Williamsonia species by Popa (2014) found no examples older than the Late Triassic globally. The AnisianLadinian age attributed to W. eskensis in our study makes this 


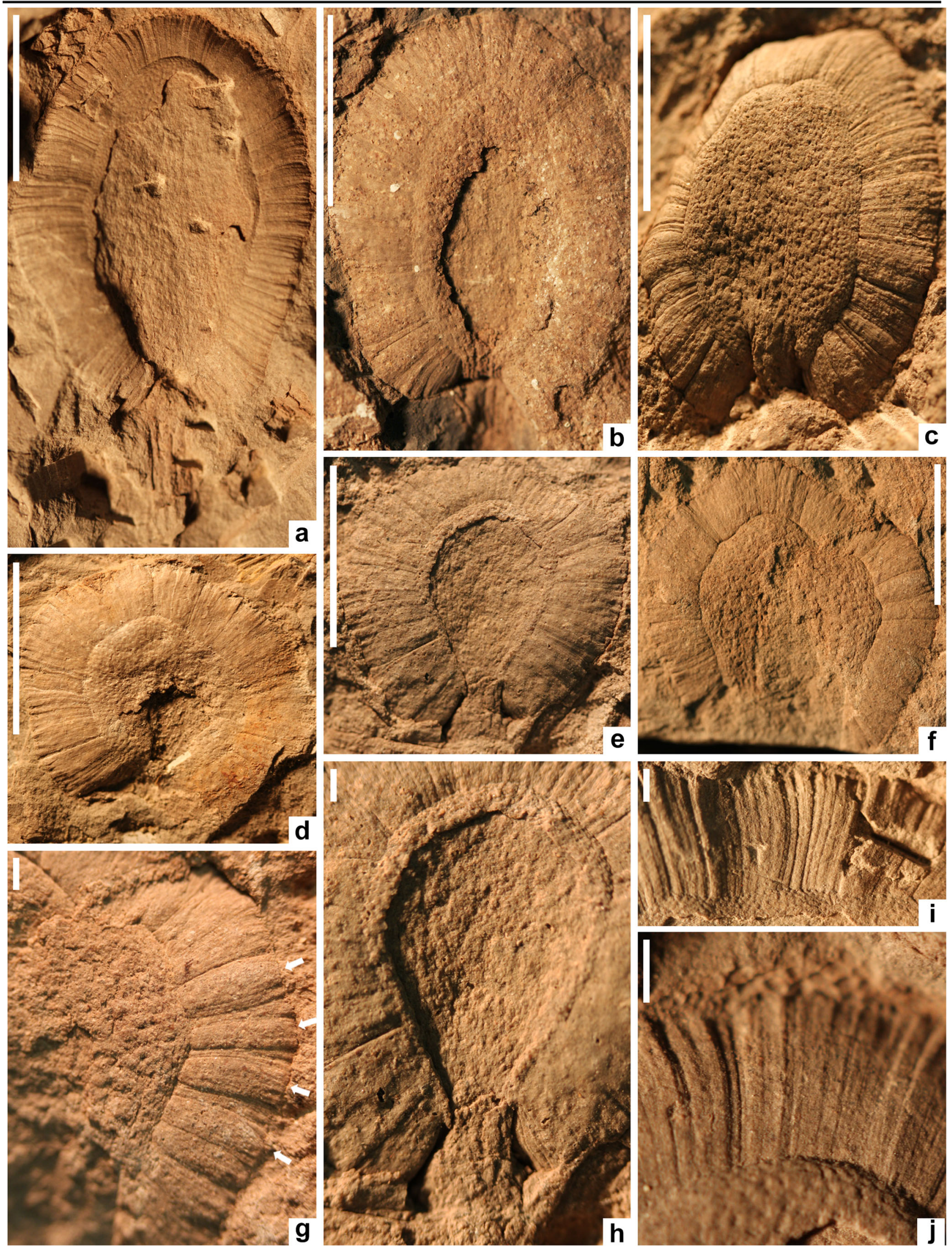


Fig. 8 Fredlindia moretonensis Shirley, 1898 comb. nov., casts and partial casts of gynoecia retaining a rim of prismatic ovules and interseminal scales. a, i, j UQF64190. b QMF2506. c QMF543. d QMF2503. e, h QMF6012.f, g AMF43500, thickened structures interpreted to be ovules are arrowed); all specimens from Denmark Hill, Ipswich Basin, southeast Queensland; Blackstone Formation (Carnian or earliest Norian). Scale bars for $\mathbf{a}-\mathbf{f}=10 \mathrm{~mm} ; \mathbf{d}-\mathbf{j}=1 \mathrm{~mm}$

the oldest reproductive structure of Bennettitales yet discovered, and among the oldest fossils that can be confidently attributed to this order. Slightly younger bennettitaleans recognised by diagnostic cuticular characters, reproductive structures or wood anatomy are known from the Molteno Formation, South Africa (Carnian: Anderson and Anderson 1989, 2003), the Chinle Formation of New Mexico (Carnian: Ash 1968), the Santa Clara Formation of Mexico (Carnian: Weber 2008), the Lunz Formation, Austria (Carnian: Pott et al. 2007a, b), the De Geerdalen Formation, Svalbard (Carnian-Norian: Strullu-Derrien et al. 2012; Pott 2014b), the Pekin Formation, eastern USA (Carnian: Pott and Axsmith 2015), and the Heiberg Formation, Arctic Canada, (Norian: Vavrek et al. 2008). Wachtler and Van Konijnenburg-van Cittert (2000) reported a leaf of Pterophyllum filicoides from the Ladinian of the Dolomites (Italy), which can be assigned to Bennettitales with considerable confidence despite the lack of any epidermal anatomy.

The widely separated occurrences of these earliest unequivocal bennettitalean fossils have long suggested that the group must have had its origins significantly earlier to have achieved such a broad geographic distribution by the Late Triassic (Pott 2014b). Clearly, the group underwent an abrupt radiation by the Late Triassic with leaves and reproductive structures of that age referable to multiple genera (Taylor et al. 2009). Various slightly older (Late Permian and Early Triassic) floras include bennettitalean-like foliage (e.g. Sze 1936; Sandberger 1864; Kawasaki 1934; Renault 1890) but, in the absence of diagnostic cuticular characters, these cannot be differentiated confidently from cycadalean leaves (Pott et al. 2010b).

Our survey of Australian bennettitopsid reproductive structures indicates that they have a scattered stratigraphic distribution and low abundance extending from the Middle Triassic to mid-Cretaceous, with sparse putative foliage remains persisting in isolated deposits of southeastern Gondwana until the Oligocene (Fig. 9). It is likely that the group as a whole originated in the Early Triassic - a time of pronounced global warmth, widespread aridity, and no development of peat-forming communities (Retallack et al. 1996). Rich plant fossil assemblages are sparse for the Early Triassic; hence, the origins of the bennettopsids may be masked by poor fossil representation of their reproductive and foliar organs during the early part of their range.
Where have all the bennettitopsid 'flowers' gone?

Among the many thousands of Australian Mesozoic plant fossils curated in national and international repositories, we were able to recognise only about 20 bennettitopsid reproductive structures of which about half belong to one species (Fredlindia moretonensis). These derive from a geochronological range of the order spanning about 210 million years (Fig. 9). Moreover, given the particularly high abundance of bennettitopsid foliage in many Australia mid-Mesozoic middle- to high-latitude deposits (Hill et al. 1999), the question arises as to why the reproductive organs (either complete or disarticulated) are so scarce.

One potential explanation is that many of the deposits containing matted foliage represent autumnal leaf banks (McLoughlin et al. 2002; Pott and McLoughlin 2014; Pott 2016), and these might exclude the reproductive organs if the latter matured and were shed in a different season. However, the absence of reproductive organs even in intervening beds seems to negate this possibility. Further, the matted foliage and reproductive organs of other late Palaeozoic and Mesozoic austral high-latitude seed ferns are typically copreserved on individual bedding planes (Holmes 1982, 1995; Drinnan and Chambers 1985, 1986; McLoughlin 1990) and bennettitalean foliage and reproductive organs elsewhere are typically preserved together (Nathorst 1902; Harris 1932, 1969; Watson and Sincock 1992; Pott and McLoughlin 2009; Pott 2014a, 2016).

A second possibility is that, although the leaves of bennettitaleans were regularly or seasonally shed, the majority of reproductive structures may have been retained on, and decayed, while still attached to the parent plant (Nathorst 1902; Pott and McLoughlin 2014). We cannot discount this possibility, especially since some Wielandiella angustifolia from southern Sweden retain the husked receptacle in attachment to the stem (Pott 2014a). Nevertheless, we note that Cycadolepis bracts (representing components of the bennettitalean perianth) were readily detached and are widely represented in Eurasian Mesozoic assemblages (Harris 1969; Watson and Sincock 1992; Pott et al. 2010a), but are scarce in Australian floras.

We have very little data on the feeding preferences of large terrestrial herbivores of the Mesozoic, except that by the latter part of that era, dinosaurs were morphologically and ecologically diverse (Barrett and Willis 2001; Sander et al. 2010); hence, some probably fed on shrub-sized bennettitaleans (Pott and McLoughlin 2014). This is supported by the identification of Ptilophyllum and Williamsonia cuticle fragments in some dinosaur coprolites (Hill 1976). However, it is unlikely that herbivory could account for the very low recovery rates of high-latitude bennettitalean reproductive organ fossils over the broad extent of the Australian sedimentary basins. 


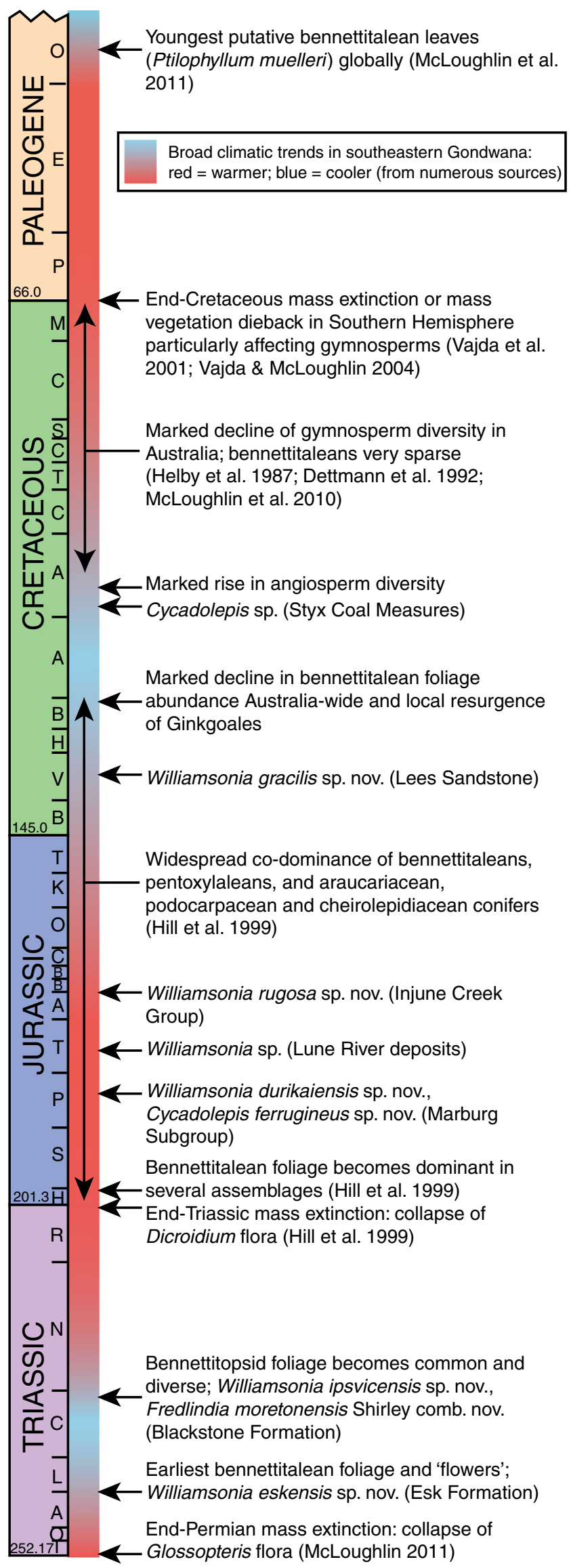

Fig. 9 Summary of the main patterns of bennettitopsid abundance and diversity through the Mesozoic and Paleogene of Australia together with the chronostratigraphic distributions of the taxa described in this study. Chronostratigraphy after Cohen et al. (2013 updated 2016); other data after Helby et al. (1987); Dettmann et al. (1992); Hill et al. (1999); Vajda et al. (2001); Vajda and McLoughlin (2004); McLoughlin (2011).

A final alternative is simply that high-latitude bennettitaleans did not produce large numbers of flowers. The small number of specimens and taxa established for bennettitalean reproductive structures from the entire Australian Mesozoic succession contrasts with at least 18 taxa from the Wealden (Early Cretaceous) of the UK (Watson and Sincock 1992), no less than 13 Williamsonia species from the Middle Jurassic to Early Cretaceous of India (Rai et al. 2016), and 6-9 taxa represented by numerous specimens from the Lunz flora (Late Triassic) of Austria (Pott et al. 2008 and references therein); all of these European and Tethyan-margin floras developed at low to middle palaeo-latitudes. Similar to the case in Australia, relatively high-palaeolatitude fossil assemblages of Argentina are rich in bennettitalean foliage but appear to contain only about four species of bennettitalean ovuliferous organs (Williamsonia species) from the entire Mesozoic (Cúneo et al. 2010).

A further notable aspect of our survey was the complete absence of polleniferous reproductive organs. A survey of around 30,000 slabs from the Upper Triassic Molteno Formation in South Africa similarly found only a very small number of polleniferous organs assigned to Weltrichia and Leguminanthus (Anderson and Anderson 2003). The dearth of these organs might relate to the same palaeobiological or taphonomic factors that produced the scarcity of ovuliferous organs.

Labandeira et al. (2007) argued that many bennettitaleans were likely pollinated by arthropods. In modern floras, there is a general trend in pollination strategies towards decreased entomophily and increased anemophily at higher latitudes (Culley et al. 2002; Kühn et al. 2006). If this was also the case in the Mesozoic, then the entomophilous pollination strategy of Bennettitales may have been less effective at high southern latitudes $\left(60^{\circ}-70^{\circ} \mathrm{S}\right)$ then occupied by Australia. At these latitudes, low-diversity forests of open structure experiencing short growth seasons may have been the norm through most of the Mesozoic (Creber and Chaloner 1985; Hill and Scriven 1995). Williamsoniaceae (of which all Australian Bennettitales appear to be members) had slender, regularly branched, divaricating stems (Watson and Sincock 1992; Pott and McLoughlin 2014; Pott et al. 2015) in contrast to the stocky, cycad-like, monopodial architecture of North American and Eurasian Cycadeoidaceae axes (Wieland 1906; Delevoryas and Hope 1976). If the austral high-latitude Williamsoniaceae were slender scrambling or even creeping plants forming dense thickets for mutual support of the stems (as in some ecologically equivalent angiosperms, e.g. Lantana spp., Rubus spp., some Banksia spp., Betula nana and Salix repens; Khoshoo and 
Mahal 1967; Suzuki 1987), then asexual regeneration via the production of adventitious roots and suckering may have been an effective reproductive strategy in this group. Extant members of Proteaceae, a group previously employed by Pott and McLoughlin (2014) as a modern structural and ecological analogue of Williamsoniaceae, reproduce clonally by root suckers after fire (He et al. 2011) or by production of adventitious roots from stems in situations of waterlogging (Poot et al. 2008). Pentoxylales, a Mesozoic group allied to Bennettitales in some phylogenetic analyses (Crane 1985), has also been interpreted to have had a bramble-like habit based on its liana-like anatomy, preservational settings and palaeocommunity associatons (Howe and Cantrill 2001). Clonal reproduction may have been a beneficial strategy for growth in fire-prone, seasonally waterlogged mire settings typically favoured by williamsoniacean bennettitaleans and pentoxylaleans. We qualify this suggestion by noting that direct evidence of suckering or adventitious roots in Australian bennettitaleans or pentoxylaleans has not yet been found, albeit that few fossils of these groups have been preserved in growth position.

\section{Preservational states}

A major drawback to the study of Australian bennettitalean fossils and extraction of phylogenetically informative characters is the scarcity of remains retaining organic matter. This is a consequence of the subdued relief, geological stability of the continent and the deep tropical to sub-tropical weathering profiles developed across much of the landscape through the Cenozoic (Gale 1992). Several Early Cretaceous assemblages from Victoria host very abundant bennettitalean leaves with organic preservation and these have yielded fine cuticular details (Douglas 1969; McLoughlin et al. 2002). However, bennettitalean reproductive organs remain unknown from these assemblages. A few Late Triassic and Middle Jurassic assemblages from coal-bearing sequences in Queensland (Ipswich and Walloon Coal Measures and their equivalents) offer some potential for cuticular investigations (Walkom 1917; Gould 1975, 1980), but few reproductive remains have been recovered from these units so far. Other coal-bearing formations (e.g. the Nymboida and Burrum Coal Measures) of coastal eastern Australia have experienced excessive thermal maturation (Russell 1994), and do not yield good quality plant cuticles (Walkom 1919; Holmes 2003; Holmes and Anderson 2008). One small assemblage of permineralized bennettitalean organs from Lower Jurassic deposits at Lune River, Tasmania (White 1991), offers future scope for analysis of axis and reproductive organ anatomical characters. The extensive occurrences of permineralized pentoxylalean, conifer, fern and angiosperm vegetative and reproductive remains in Middle Jurassic and Upper Cretaceous strata of the Surat and Eromanga basins, Queensland (Peters and Christophel
1978; White 1986; Tidwell and Clifford 1995; Tidwell and Rozefelds 1990; Dettmann et al. 2009, 2012) offer some potential for future discoveries of anatomically preserved bennettitalean organs but such organs have not been identified to date.

\section{Provincialism}

Given that cuticular details are unknown for most Australian bennettitalean leaves and reproductive organs, identifications have relied predominantly on comparison of gross morphological features and venation characters (Etheridge 1888; Walkom 1917, 1921; Jones and de Jersey 1947; Douglas 1969; Gould 1975, McLoughlin 1996; McLoughlin et al. 2000, 2010, 2011; Holmes and Anderson 2008; McLoughlin and Pott 2009; McLoughlin et al. 2010). The conservative pinnate architecture of bennettitalean leaves has meant that many Australian specimens have been assigned by previous workers to species based on type material from India or even Europe. Meyen (1987) noted a decreased level of provincialism in the global floras in the mid-Mesozoic when Pangea was at its maximum extent. Near global distributions are known among some Mesozoic spore/pollen morphotypes (e.g. Classopollis spp.; Srivastava 1976) and, in the modern world, a small number of extant plant genera (e.g. Ranunculus Emadzade et al. 2011) reach near cosmopolitan distributions even overcoming significant disjunctions between landmasses. However, such worldwide ranges of advanced seed plants would not be expected at species level, especially following initiation of the breakup of Pangaea (in the latest Triassic to Early Jurassic: Vaughan and Storey 2007) and the resulting increased likelihood of allopatric speciation. Although belonging to widespread fossil-genera, the bennettitalean reproductive structures described from Australia are assigned to new species and differ from congeneric forms elsewhere in Gondwana and Laurasia by their gross size, bract dimensions and bract ornamentation. This supports the concept of significant latitudinally defined species-level provincialism in the mid-Mesozoic floras of Gondwana based on studies of some other plant groups (Dettmann and Clifford 1992; Srivastava 1994) and warrants reappraisal of the identities of the many Australian fossil leaves assigned in early palaeobotanical studies to species established in Laurasia.

\section{Conclusions}

Bennettitopsids were major components of many Mesozoic floras globally. In Australia, they are widely and abundantly represented from Middle Triassic to mid-Cretaceous strata, mostly by leaf impression fossils. The Late Cretaceous saw a marked decline of the group globally, with the putative latest 
representatives persisting in high-latitude refugia of eastern Australia until the Oligocene. Despite rich collections of bennettitalean foliage, only six distinct forms of Williamsonia represented by very few specimens were recognised from extensive fieldwork and a survey of many thousands of Australian Mesozoic plant fossils held in institutional repositories. Together with only a single species of Fredlindia and a few dispersed Cycadolepis bracts, we infer that this very low representation of Williamsonia is unlikely to be a simple sampling bias and that bennettitopsids occupying high-latitude austral regions may have adopted supplementary (vegetative) reproductive strategies to maintain their populations and/or retained their reproductive structures on the host plant until decay. The thin-stalked, divaricate-branching, shrubby or scrambling nature of most williamsoniacean bennettites, and their occupation of densely vegetated mire environments in many areas, may have facilitated adventitious root production from substrate-touching branches and/or suckering from shallow root systems. In turn, these strategies may have had ecological benefits in dealing with environmental variables, such as fire and waterlogging in densely vegetated floodplain and mire settings.

Acknowledgements We thank Mihai Popa (Bucharest, Romania) and John Anderson (South African National Biodiversity Institute) for their constructive comments on the manuscript. We greatly appreciate the help of Kristin Spring, Alex Cook and Andrew Rozefelds (Queensland Museum); Shen Yong-yi and Ian Percival (Australian Museum and Geological Survey of New South Wales); John Laurie (Geoscience Australia); the late David Pickering (Museum Victoria); Kris Brimmell (Western Australian Museum); Peta Hayes (The Natural History Museum, London); Pradip Sarkar (Curatorial Division of the Geological Survey of India); Rajni Tewari and Deepa Agnihotri (Birbal Sahni Institute of Palaeosciences); and Analia Artabe (Facultad de Ciencias Naturales y Museo, Universidad Nacional de La Plata) for assistance in accessing the fossil collections under their care. Financial support to Stephen McLoughlin by the Swedish Research Council (VR grant 2014-5234) and the National Science Foundation (project \#1636625) is gratefully acknowledged. Christian Pott acknowledges funding from the German and Swedish Research Councils (DFG KR2125/3, VR 2012-4375) and from the 'Friends of the Swedish Museum of Natural History' (Riksmusei Vänner, Stockholm) and funding through SYNTHESYS (AT-TAF 467).

\section{Compliance with ethical standards}

Conflict of interest: The authors declare that they have no conflict of interest.

Open Access This article is distributed under the terms of the Creative Commons Attribution 4.0 International License (http:// creativecommons.org/licenses/by/4.0/), which permits unrestricted use, distribution, and reproduction in any medium, provided you give appropriate credit to the original author(s) and the source, provide a link to the Creative Commons license, and indicate if changes were made.

\section{References}

Anderson, J. M., \& Anderson, H. M. (1989). Palaeoflora of southern Africa. Molteno Formation (Triassic) Volume 2. Gymnosperms (excluding Dicroidium). Rotterdam: A.A. Balkema.

Anderson, J. M., \& Anderson, H. M. (2003). Heyday of the Gymnosperms: systematics and biodiversity of the Late Triassic Molteno fructifications. Pretoria: South African National Biodiversity Institute.

Anderson, J. M., Anderson, H. M., Archangelsky, S., Bamford, M., Chandra, S., Dettmann, M. E., Hill, R. S., McLoughlin, S., \& Rösler, O. (1999). Patterns of Gondwana plant colonisation and diversification. African Journal of Earth Sciences, 28, 145-167.

Anderson, J. M., Anderson, H. M. \& Cleal, C.J. (2007). Brief History of the Gymnosperms: classification, biodiversity, phytogeography and ecology. Pretoria: South African National Biodiversity Institute. Strelitzia 20.

Andrews, H. N. (1970). Index of generic names of fossil plants. US Geological Survey Bulletin, 1300, 1-354.

Ash, S. R. (1968). A new species of Williamsonia from the Upper Triassic Chinle Formation of New Mexico. Journal of the Linnean Society, Botany, 61, 113-120.

Balme, B. E. (1995). Fossil in situ spores and pollen grains: an annotated catalogue. Review of Palaeobotany and Palynology, 87, 81-323.

Barrett, P. M., \& Willis, K. J. (2001). Did dinosaurs invent flowers? Dinosaur-angiosperm coevolution revisited. Biological Reviews, 76, 411-447.

Bose, M. N. (1966). A petrified bennettitalean flower from the Rajmahal Hills, India. Current Science, 22, 559-570.

Bose, M. N. (1968). A new species of Williamsonia from the Rajmahal Hills, India. Journal of the Linnean Society (Botany), 61, 121-127.

Bose, M. N., \& Kasat, M. L. (1972). The genus Ptilophyllum in India. The Palaeobotanist, 19, 115-145.

Bose, M. N., Banerji, J., \& Pal, P. K. (1984). Amarjolia dactylota (Bose) comb. nov., a bennettitalean bisexual flower from the Rajmahal Hills, India. The Palaeobotanist, 32, 217-229.

Bromfield, K., Burrett, C. F., Leslie, R. A., \& Meffre, S. (2007). Jurassic volcaniclastic - basaltic andesite - dolerite sequence in Tasmania: new age constraints for fossil plants from Lune River. Australian Journal of Earth Sciences, 54, 965-974.

Burger, D. (1968). Stratigraphy and palynology of upper Mesozoic sections in some deep wells in the Surat Basin, Queensland. Bureau of Mineral Resources, Australia, Record, 1968 24, 1-35.

Burger, D. (1980). Palynology of the Lower Cretaceous in the Surat Basin. Bureau of Mineral Resources Geology and Geophysics Bulletin, 189, 1-106.

Burger, D., (1994). Palynological studies of the Bundamba Group and Walloon Coal Measures in the Clarence-Moreton Basin. In A. T. Wells \& P. E. O'Brien (Eds), Geology and Petroleum Potential of the Clarence-Moreton Basin, New South Wales and Queensland. Canberra: AGSO Bulletin, 241, 164-180.

Campbell, L. M., Holcombe, R. J., \& Fielding, C. R. (1999). The Esk Basin - a Triassic foreland basin within the northern New England Orogen. In P. G. Flood (Ed.), Regional Geology, Tectonics and Metallogenesis - New England Orogen (NEO'99 Conference) (pp. 275-284). Armidale: Earth Sciences, University of New England.

Carruthers, W. (1870). On fossil cycadean stems from the secondary rocks of Britain. Linnean Society of London Transactions, 26 , 675-708.

Clifford, H. T. (1998). First record of Caytonia in Australia. Memoirs of the Queensland Museum, 42, 448.

Cohen, K. M., Finney, S. C., Gibbard, P. L., \& Fan, J.-X. (2013). The ICS international chronostratigraphic chart. Episodes, 36, 199-204.

Cook, A., \& Rozefelds, A. (2015). In Search of Ancient Queensland. Brisbane: Queensland Museum. 
Crane, P. R. (1985). Phylogenetic analysis of seed plants and the origin of angiosperms. Annals of the Missouri Botanical Garden, 72, 716793.

Crane, P. R. (1988). Major clades and relationships in the "higher" gymnosperms. In C. Beck (Ed.), The Origin and Evolution of Gymnosperms (pp. 218-272). New York: Columbia University Press.

Crane, P. R., \& Herendeen, P. S. (2009). Bennettitales from the Grisethorpe bed (Middle Jurassic) at Cayton Bay, Yorkshire, UK. American Journal of Botany, 96, 284-295.

Cranfield, L. C., McElroy, C. T., \& Schwarzbock, C. F. (1975). ClarenceMoreton Basin, N.S.W. and Queensland. In D. M. Traves \& D. King (Eds.), Economic Geology of Australia and Papua New Guinea: coal (pp. 328-333). Parkville: Australian Institute of Mining and Metallurgy.

Creber, G. T., \& Chaloner, W. G. (1985). Tree growth in the Mesozoic and Early Tertiary and the reconstruction of palaeoclimates. Palaeogeography, Palaeoclimatology, Palaeoecology, 52, 35-60.

Crepet, W. L. (1972). Investigations of North American cycadeoids: pollination mechanisms in Cycadeoidea. American Journal of Botany, 59, 1048-1056.

Crepet, W. L. (1974). Investigations of North American cycadeoids: the reproductive biology of Cycadeoidea. Palaeontographica B, 148, 144-169.

Crepet, W. L., \& Stevenson, D. M. (2010). The Bennettitales (Cycadeoidales): a preliminary perspective of this arguably enigmatic group. In C. T. Gee (Ed.), Plants in Mesozoic Time: morphological innovations, phylogeny, ecosystems (pp. 215-244). Bloomington: Indiana University Press.

Culley, T. M., Weller, S. G., \& Sakai, A. K. (2002). The evolution of wind pollination in angiosperms. Trends in Ecology \& Evolution, 17, 361-369.

Cúneo, N. R., Escapa, I., Villar de Seoane, L., Artabe, A., \& Gnaedinger, S. (2010). Review of the cycads and bennettitaleans from the Mesozoic of Argentina. In C. T. Gee (Ed.), Plants in Mesozoic Time: morphological innovations, phylogeny, ecosystems (pp. 187-212). Bloomington: Indiana University Press.

Day, R. W., Whitaker, W. G., Murray, C. G., Wilson, I. H., \& Grimes, K. G. (1983). Queensland geology. Geological Survey of Queensland Publication, 383, 1-194.

Delevoryas, T. (1963). Investigations of North American cycadeoids: cones of Cycadeoidea. American Journal of Botany, 50, 45-52.

Delevoryas, T. (1968). Investigations of North American cycadeoids: structure, ontogeny and phylogenetic considerations of cones of Cycadeoidea. Palaeontographica B, 121, 122-133.

Delevoryas, T., \& Gould, R. E. (1973). Investigations of North American cycadeoids: williamsonian cones from the Jurassic of Oaxaca, Mexico. Review of Palaeobotany and Palynology, 15, 27-42.

Delevoryas, T., \& Hope, R. C. (1976). More evidence for a slender growth habit in Mesozoic cycadophytes. Review of Palaeobotany and Palynology, 21, 93-100.

Dettmann, M. E., \& Clifford, H. T. (1992). Phylogeny and biogeography of Ruffordia, Mohria and Anemia (Schizaeaceae) and Ceratopteris (Pteridaceae): evidence from in situ and dispersed spores. Alcheringa, 16, 269-314.

Dettmann, M. E., Molnar, R. E., Douglas, J. G., Burger, D., Fielding, C., Clifford, H. T., Francis, J., Jell, P., Rich, T., Wade, M., Rich, P. V., Pledge, N., Kemp, A., \& Rozefelds, A. (1992). Australian Cretaceous terrestrial faunas and floras: biostratigraphic and biogeographic implications. Cretaceous Research, 13, 207-262.

Dettmann, M. E., Clifford, H. T., \& Peters, M. (2009). Lovellea wintonensis gen. et sp. nov.-Early Cretaceous (late Albian), anatomically preserved, angiospermous flowers and fruits from the Winton Formation, western Queensland, Australia. Cretaceous Research, 30, 339-355.
Dettmann, M. E., Clifford, H. T., \& Peters, M. (2012). Emwadea microcarpa gen. et $\mathrm{sp}$. nov. - anatomically preserved araucarian seed cones from the Winton Formation (late Albian), western Queensland, Australia. Alcheringa, 36, 217-237.

Donoghue, M. J., \& Doyle, J. A. (2000). Seed plant phylogeny: demise of the anthophyte hypothesis? Current Biology, 10, 106-109.

Douglas, J. G. (1969). The Mesozoic floras of Victoria, parts $1 \& 2$ Memoirs of the Geological Survey of Victoria, 28, 1-310.

Doyle, J. A. (2006). Seed ferns and the origin of angiosperms. Journal of the Torrey Botanical Society, 133, 169-209.

Drinnan, A. N., \& Chambers, T. C. (1985). A reassessment of Taeniopteris daintreei from the Victorian Early Cretaceous: a member of the Pentoxylales and a significant Gondwanaland plant. Australian Journal of Botany, 33, 89-100.

Drinnan, A. N., \& Chambers, T. C. (1986). Flora of the Lower Cretaceous Koonwarra fossil bed (Korumburra Group), South Gippsland, Victoria. Memoirs of the Association of Australasian Palaeontologists, 3, 1-77.

Dunstan, B. (1916). Mesozoic and Tertiary insects of Queensland and New South Wales. Stratigraphical features. Geological Survey of Queensland Publication, 253, 1-10.

Emadzade, K., Gehrke, B., Linder, H. P., \& Hörandl, E. (2011). The biogeographical history of the cosmopolitan genus Ranunculus L. (Ranunculaceae) in the temperate to meridional zones. Molecular Phylogenetics and Evolution, 58, 4-21.

Engler, A. (1892). Syllabus der Vorlesungen über specielle und medicinisch-pharmaceutische Botanik [XXIII+184]. Berlin: Gebruder Borntraeger.

Engler, A. (1897). Die natürlichen Pflanzenfamilien, Nachträge zum IIIV Teil. Leipzig: Engelmann.

Etheridge Jr., R. (1888). Additions to the fossil flora of eastern Australia. Proceedings of the Linnean Society of New South Wales, 13, 1300 1309.

Etheridge Jr., R. (1890). Notes on the fructification of Phlebopteris alethopteroides Eth. Fil., from the lower Mesozoic beds of Queensland. Proceedings of the Linnean Society of New South Wales, 14, 625-626.

Exon, N. F. (1976). Geology of the Surat Basin in Queensland. Bureau of Mineral Resources, Australia, Bulletin, 166, 1-160.

Farr, E. R., \& Zijlstra, G. eds. (1996+). Index nominum genericorum (Plantarum). http://botany.si.edu/ing/ (accessed: 30.01.2017).

Feistmantel, O. (1890). Geological and palaeontological relations of the coal and plant bearing beds of Mesozoic age in eastern Australia and Tasmania: with special reference to the fossil flora, described, illustrated, and compared with analogous deposits in other countries. Memoirs of the Geological Survey of New South Wales, Palaeontology, 3, 1-183.

Fielding, C. R. (1992). A review of Cretaceous coal-bearing sequences in Australia. Geological Society of America Special Paper, 267, 303 324.

Florin, R. (1933). Zur Kenntnis der Spaltöffnungsapparate der Bennettitales. Kungliga Svenska Vetenskapsakademiens Handlingar, Tredje Serien, 12, 11-31.

Friis, E. M., Crane, P. R., Pedersen, K. R., Bengtson, S., Donoghue, P. C. J., Grimm, G. W., \& Stampanoni, M. (2007). Phase-contrast X-ray microphotography links Cretaceous seeds with Gnetales and Bennettitales. Nature, 450, 549-552.

Friis, E. M., Pedersen, K. R., \& Crane, P. R. (2009). Early Cretaceous mesofossils from Portugal and eastern North America related to the Bennettitales-Erdtmanithecales-Gnetales group. American Journal of Botany, 96, 252-283.

Gale, S. J. (1992). Long-term landscape evolution in Australia. Earth Surface Processes and Landforms, 17, 323-343.

Gee, C. T. (1989). Revision of the Late Jurassic/Early Cretaceous flora from Hope Bay, Antarctica. Palaeontographica, 213B, 149-214. 
Goscombe, P. W., \& Coxhead, B. A. (1995). Clarence-Moreton, Surat, Eromanga, Nambour, and Mulgildie basins. In C. R. Ward, H. J. Harrington, C. W. Mallett, \& J. W. Beeston (Eds.), Geology of Australian Coal Basins (pp. 489-511). Sydney: Geological Society of Australia Coal Geology Group Special Publication 1.

Gould, R. E. (1968). Morphology of Equisetum laterale Phillips, 1829, and E. bryanii sp. nov. from the Mesozoic of south-eastern Queensland. Australian Journal of Botany, 16, 153-176.

Gould, R. E. (1971). Report on plant fossils from Durikai, southeastern Queensland. Appendix 3. In N. F. Exon, R. F. Reiser, D. J. Casey, \& R. L. Brunker. The post-Palaeozoic rocks of the Warwick 1:250 000 Sheet area, Queensland and New South Wales. Bureau of Mineral Resources, Geology and Geophysics, Australia, Report, 140, 63-64.

Gould, R. E. (1974). The fossil flora of the Walloon Coal Measures: a survey. Proceedings of the Royal Society of Queensland, 85, 33-41.

Gould, R. E. (1975). The succession of Australian pre-Tertiary megafossil floras. Botanical Review, 41, 453-483.

Gould, R. E. (1980). The coal-forming flora of the Walloon Coal Measures. Australian Coal Geology, 1, 83-105.

Halle, T. G. (1913). The Mesozoic flora of Graham Land. Wissenschaftliche Ergebnisse der Schwedischen Südpolar-Expedition, 1901-1903(3), $1-123$.

Harris, T. M. (1932). The fossil flora of Scoresby Sound East Greenland-Part 3: Caytoniales and Bennettitales. Meddelelser om Grønland, 85, 1-133.

Harris, T. M. (1944). A revision of Williamsoniella. Philosophical Transactions of the Royal Society of London. Series B. Biological Sciences, 231, 313-328.

Harris, T. M. (1953). Notes on the Jurassic flora of Yorkshire, 58-60. 58. Bennettitalean scale leaves; 59. Williamsonia himas sp. n.; 60. Williamsonia setosa Nathorst. Annals and Magazine of Natural History, London, 12(6), 33-52.

Harris, T. M. (1969). The Yorkshire Jurassic Flora, III, Bennettitales. London: British Museum (Natural History).

He, T., Lamont, B. B., \& Downes, K. S. (2011). Banksia - born to burn. New Phytologist, 191, 184-196.

Helby, R., Morgan, R., \& Partridge, A. D. (1987). A palynological zonation of the Australian Mesozoic. Memoir of the Association of Australasian Palaeontologists, 4, 1-94.

Hill, C. R. (1976). Coprolites of Ptilophyllum cuticles from the Middle Jurassic of North Yorkshire. Bulletin of the British Museum (Natural History). Geology, 27, 289-293.

Hill, R. S., \& Scriven, L. J. (1995). The angiosperm-dominated woody vegetation of Antarctica: a review. Review of Palaeobotany and Palynology, 86, 175-198.

Hill, D., Playford, G., \& Woods, J. T. (1965). Triassic Fossils of Queensland. Brisbane: Queensland Palaeontographical Society.

Hill, D., Playford, G., \& Woods, J. T. (1966). Jurassic Fossils of Queensland. Brisbane: Queensland Palaeontographical Society.

Hill, R. S., Truswell, E. M., McLoughlin, S., \& Dettmann, M. E. (1999). The evolution of the Australian flora: fossil evidence. In A. E. Orchard (Ed.), Flora of Australia, 2nd Edition, 1 (Introduction) (pp. 251-320). Melbourne: CSIRO.

Hilton, J., \& Bateman, R. M. (2006). Pteridosperms are the backbone of seed-plant phylogeny. Journal of the Torrey Botanical Society, 133, $119-168$.

Holmes, W. B. K. (1982). The Middle Triassic flora from Benolong near Dubbo, central-western New South Wales. Alcheringa, 6, 1-33.

Holmes, W. B. K. (1995). The Late Permian megafossil flora from Cooyal, New South Wales, Australia. In D. D. Pant (Ed.), Global Environment and Diversification of Plants through Geological Time (pp. 123-152). Allahabad: Birbal Sahni Centenary Volume.

Holmes, W. B. K. (2003). The Middle Triassic megafossil flora of the Basin Creek Formation, Nymboida Coal Measures, New South Wales, Australia. Part 3. Fern-like foliage. Proceedings of the Linnean Society of New South Wales, 124, 53-108.
Holmes, W. B. K., \& Anderson, H. M. (2008). The Middle Triassic megafossil flora of the Basin Creek Formation. Nymboida Coal Measures, NSW, Australia. Part 7. Cycadophyta. Proceedings of the Linnean Society of New South Wales, 129, 113-149.

Howe, J., \& Cantrill, D. J. (2001). Palaeoecology and taxonomy of Pentoxylales from the Albian of Antarctica. Cretaceous Research, 22, 779-793.

Jansson, I.-M., McLoughlin, S., \& Vajda, V. (2008a). Early Jurassic annelid cocoons from eastern Australia. Alcheringa, 32, 285-296.

Jansson, I.-M., McLoughlin, S., Vajda, V., \& Pole, M. (2008b). An Early Jurassic flora from the Clarence-Moreton Basin, Australia. Review of Palaeobotany and Palynology, 150, 5-21.

Jell, P. A. (2004). The fossil insects of Australia. Memoirs of the Queensland Museum, 50, 1-124.

Jersey, N. J., de (1970). Triassic miospores from the Blackstone Formation, Aberdare Conglomerate and Raceview Formation. Geological Survey of Queensland Publication, 348, Palaeontological Papers, 22, 1-24.

Jersey, N. J., de (1975). Miospore zones in the lower Mesozoic of southeastern Queensland. In K. S. W. Campbell (Ed.), Gondwana Geology (pp. 159-172). Canberra: Australian National University Press.

Jones, O. A., \& de Jersey, N. J. (1947). The flora of the Ipswich Coal Measures - morphology and succession. Papers of the Department of Geology, University of Queensland, 3(3), 1-88.

Kawasaki, S. (1934). The flora of the Heian system - part 2. Bulletin of the Geological Survey of Chosen (Korea), 6, 47-311 [195-197].

Khoshoo, T. N., \& Mahal, C. (1967). Versatile reproduction in Lantana camara. Current Science, 8, 200-203.

Kräusel, R. (1949). Koniferen und andere Gymnospermen aus der Trias von Lunz, Nieder-Österreich. Palaeontographica B, 89, 35-82.

Kühn, I., Bierman, S. M., Durka, W., \& Klotz, S. (2006). Relating geographical variation in pollination types to environmental and spatial factors using novel statistical methods. New Phytologist, 172, 127139.

Labandeira, C. C., Kvaček, J., \& Mostovski, M. B. (2007). Pollination drops, pollen, and insect pollination of Mesozoic gymnosperms. Taxon, 56, 663-695.

Lignier, O. (1894). Végétative fossiles de Normandie. Structure et affinities du Bennettitites Morieri (Sap. \& Mar.) Mémories de la Société linnéenne de Normandie, Caen, 18, 5-78.

Lindley, J., \& Hutton, W. (1833-1836). The Fossil Flora of Great Britain, or figures and descriptions of the vegetable remains found in a fossil state in the country. London: James Ridgway.

Mathews, S. (2009). Phylogenetic relationships among seed plants: persistent questions and the limits of molecular data. American Journal of Botany, 96, 288-236.

McLoughin, S., \& Pott, C. (2009). The Jurassic flora of Western Australia. GFF, 131, 113-136.

McLoughlin, S. (1990). Some Permian glossopterid fructifications and leaves from the Bowen Basin, Queensland, Australia. Review of Palaeobotany and Palynology, 62, 11-40.

McLoughlin, S. (1996). Early Cretaceous macrofloras of Western Australia. Records of the Western Australian Museum, 18, 19-65.

McLoughlin, S. (2011). Glossopteris - insights into the architecture and relationships of an iconic Permian Gondwanan plant. Journal of the Botanical Society of Bengal, 65(2), 93-106.

McLoughlin, S., \& Drinnan, A. N. (1995). A Middle Jurassic flora from the Walloon Coal Measures, Mutdapilly, Queensland, Australia. Memoirs of the Queensland Museum, 38, 257-272.

McLoughlin, S., \& Hill, R. S. (1996). The succession of Western Australian Phanerozoic floras. In S. D. Hopper, J. A. Chappill, M. S. Harvey, \& A. S. George (Eds.), Gondwanan Heritage: past, present and future of the Western Australian biota. Proceedings of the Conference on Systematics, Evolution and Conservation of the Western Australian Biota, Perth, 1993 (pp. 61-80). Surrey Beatty: Sydney. 
McLoughlin, S., \& McNamara, K. (2001). Ancient Floras of Western Australia. Perth: Publication of the Department of Earth and Planetary Sciences, Western Australian Museum.

McLoughlin, S., \& Pott, C. (2010). On the trail of Australia's youngest Bennettitales. Australian age of Dinosaurs, 8, 6-7.

McLoughlin, S., Tosolini, A.-M. P., \& Drinnan, A. N. (2000). Revision of an Early Cretaceous macroflora from the Maryborough Formation, Maryborough Basin, Queensland, Australia. Memoirs of the Queensland Museum, 45, 483-503.

McLoughlin, S., Tosolini, A.-M. P., Nagalingum, N. S., \& Drinnan, A. N. (2002). Early Cretaceous (Neocomian) flora and fauna of the lower Strzelecki Group, Gippsland Basin, Victoria. Association of Australasian Palaeontologists Memoir, 26, 1-144.

McLoughlin, S., Pott, C., \& Elliott, D. (2010). The Winton Formation flora (Albian-Cenomanian, Eromanga Basin): implications for vascular plant diversification and decline in the Australian Cretaceous. Alcheringa, 34, 303-322.

McLoughlin, S., Carpenter, R. J., \& Pott, C. (2011). Ptilophyllum muelleri (Ettingsh.) comb. nov. from the Oligocene of Australia: last of the Bennettitales? International Journal of Plant Sciences, 172, $574-585$.

McLoughlin, S., Jansson, I.-M., \& Vajda, V. (2014). Megaspore and microfossil assemblages reveal diverse herbaceous lycophytes in the Australian Early Jurassic flora. Grana, 53, 22-53.

McLoughlin, S., Martin, S. K., \& Beattie, R. (2015). The record of Australian Jurassic plant-arthropod interactions. Gondwana Research, 27, 940-959.

McNeill, J., Barrie, F. R., Buck, W. R., Demoulin, V., Greuter, W., Hawkesworth, D. L., Herendeen, P. S., Knapp, S., Marhold, K., Prado, J., Prud'homme van Reine, W. F., Smith, G. F., Wiersema, J. H., \& Turland, N. J. (2012). International Code of Nomenclature for algae, fungi, and plants (Melbourne Code), adopted by the Eighteenth International Botanical Congress Melbourne, Australia, July 2011. Königstein: A. R. G. Gantner Verlag, Koeltz Scientific Books, [Regnum Veg. 154].

Meyen, S. V. (1987). Fundamentals of Palaeobotany. London: Chapman and Hall.

Nathorst, A. G. (1880). Några anmärkningar om Williamsonia, Carruthers. Öfversikt af Kongliga Vetenskaps-Akademiens Förhandlingar, 9, 33-52.

Nathorst, A. G. (1888). Nya anmärkningar om Williamsonia. Öfversigt af Konglika Vetenskaps-Akademiens Förhandlingar, 6, 359-365.

Nathorst, A. G. (1902). Beiträge zur Kenntnis einiger mesozoischer Cycadophyten. Kungliga Svenska Vetenskapsakademiens Handlingar, 36, 1-28.

Nathorst, A. G. (1909). Paläobotanische Mitteilungen 8. Über Williamsonia, Wielandia, Cycadocephalus und Weltrichia. Kungliga Svenska Vetenskapsakademiens Handlingar, 45, 3 37.

Nathorst, A. G. (1913). How are the names Williamsonia and Wielandiella to be used? - a question of nomenclature. Geologiska Föreningens I Stockholm Förhandlingar, 35, 361-366.

Nixon, K. C., Crepet, W. L., Stevenson, D., \& Friis, E. M. (1994). A reevaluation of seed plant phylogeny. Annals of the Missouri Botanical Garden, 81, 484-533.

O'Brien, P. E., \& Wells, A. T. (1994). Sedimentology of the Bundamba Group. In A. T. Wells \& P. E. O'Brien (Eds.), Geology and Petroleum Potential of the Clarence-Moreton Basin (pp. 72-137). New South Wales and Queensland: Australian Geological Survey Organisation, Bulletin 241.

Pattemore, G. A., \& Rigby, J. F. (2005). Fructifications and foliage from the Mesozoic of southeast Queensland. Memoirs of the Queensland Museum, 50, 329-345.

Pedersen, K. R., Crane, P. R., \& Friis, E. M. (1989). The morphology and phylogenetic significance of Vardekloeftia Harris (Bennettitales). Review of Palaeobotany and Palynology, 60, 7-24.
Peters, M. D., \& Christophel, D. C. (1978). Austrosequoia wintonensis, a new taxodiaceous cone from Queensland, Australia. Canadian Journal of Botany, 56, 3119-3128.

Pole, M. S., \& Douglas, J. G. (1999). Bennettitales, Cycadales and Ginkgoales from the mid Cretaceous of the Eromanga Basin, Queensland, Australia. Cretaceous Research, 20, 523-538.

Poot, P., Bakker, R., \& Lambers, H. (2008). Adaptations to winter-wet ironstone soils: a comparison between rare ironstone Hakea (Proteaceae) species and their common congeners. Australian Journal of Botany, 56, 574-582.

Popa, M. E. (2014). Early Jurassic bennettitalean reproductive structures of Romania. Palaeobiodiversity and Palaeoenvironments, 94, 327 362.

Pott, C. (2014a). A revision of Wielandiella angustifolia - a shrub-sized bennettite from the Rhaetian-Hettangian of Scania, Sweden, and Jameson Land, Greenland. International Journal of Plant Sciences, 175, 467-499.

Pott, C. (2014b). The Triassic flora of Svalbard. Acta Palaeontologica Polonica, 59, 709-740.

Pott, C. (2016). Westersheimia pramelreuthensis from the Carnian (Upper Triassic) of Lunz, Austria: More evidence for a unitegmic seed coat in early Bennettitales. International Journal of Plant Sciences, 177, 771-791.

Pott, C., \& Axsmith, B. J. (2015). Williamsonia carolinensis sp. nov. and associated Eoginkgoites foliage from the Upper Triassic Pekin Formation: implications for early evolution in Williamsoniaceae (Bennettitales). International Journal of Plant Sciences, 175, 174 185.

Pott, C., \& McLoughlin, S. (2009). Bennettitalean foliage from the Rhaetian-Bajocian (latest Triassic-Middle Jurassic) floras of Scania, southern Sweden. Review of Palaeobotany and Palynology, 158, 117-166.

Pott, C., \& McLoughlin, S. (2014). Divaricate growth habit in Williamsoniaceae (Bennettitales): unravelling the ecology of a key Mesozoic plant group. Palaeobiodiversity and Palaeoenvironments, 94, 307-325.

Pott, C., Krings, M., \& Kerp, H. (2007a). First record of Nilssoniopteris (Gymnospermophyta, Bennettitales) from the Carnian (Upper Triassic) of Lunz, Lower Austria. Palaeontology, 50, 1299-1318.

Pott, C., Van Konijnenburg-van Cittert, J. H. A., Kerp, H., \& Krings, M. (2007b). Revision of the Pterophyllum species (Cycadophytina: Bennettitales) in the Carnian (Late Triassic) flora from Lunz, Lower Austria. Review of Palaeobotany and Palynology, 147, 3-27.

Pott, C., Krings, M., \& Kerp, H. (2008). The Carnian (Late Triassic) flora from Lunz in Lower Austria: paleoecological considerations. Palaeoworld, 17, 172-182.

Pott, C., Krings, M., Kerp, H., \& Friis, E. M. (2010a). Reconstruction of a bennettitalean flower from the Carnian (Upper Triassic) of Lunz, Lower Austria. Review of Palaeobotany and Palynology, 159, 94 111.

Pott, C., McLoughlin, S., \& Lindström, A. (2010b). Late Palaeozoic foliage from China displays affinities to Cycadales rather than to Bennettitales necessitating a re-evaluation of the Palaeozoic Pterophyllum species. Acta Palaeontologia Polonica, 55, 157-168.

Pott, C., Guhl, M., \& Lehmann, J. (2014). The Early Cretaceous flora from the Wealden facies at Duingen, Germany. Review of Palaeobotany and Palynology, 201, 75-105.

Pott, C., Wang, X., \& Zheng, X. (2015). Wielandiella villosa comb. nov. from the Middle Jurassic of Daohugou, China: more evidence for divaricate plant architecture in Williamsoniaceae. Botanica Pacifica, $4,137-148$.

Pott, C., Schmeissner, S., Dütsch, G., \& van Konijnenburg-van Cittert, J. H. A. (2016). Bennettitales in the Rhaetian flora of Wüstenwelsberg, Bavaria, Germany. Review of Palaeobotany and Palynology, 232, 98-118. 
Pott, C., Fischer, T., \& Aschauer, B. (2017). Lunzia austriaca-a bennettitalean microsporangiate structure with Cycadopites-like in situ pollen from the Carnian (Upper Triassic) of Lunz. Austria. Grana. doi:10.1080/00173134.2017.1282010.

Raciborski, M. (1893). Cycadeoidea niedzwiedzkii nov. sp. Rozpraw Wydziału matematyczno-przyrodniczego Akademii Umiejetności w Krakowie, 26, 301-310.

Rai, J., Prakash, N., Pandey, D. K., Fürsich, F. T., Alberti, M., Singh, A., Garg, S., \& Swami, N. (2016). A Middle Oxfordian (Jurassic) flora from the Kachchh Basin, western India, with the earliest record of bennettitaleans from the subcontinent. Geophytology, 46, 133-146.

Rees, P. M., \& Cleal, C. J. (2004). Lower Jurassic floras from Hope Bay and Botany Bay, Antarctica. Special Papers in Palaeontology, 72, $1-90$.

Renault, M. B. (1890). Cycadées. In M. B. Renault \& R. Zeiller (Eds.), Études sur le terrain Houiller de Commentry-Livre deuxièmeFlore fossile (pp. 613-625). Saint Étienne: Théolier et Compagnie.

Retallack, G. J. (1981). Middle Triassic megafossil plants from Long Gully, near Otematata, north Otago, New Zealand. Journal of the Royal Society of New Zealand, 11, 167-200.

Retallack, G. J., Veevers, J. J., \& Morante, R. (1996). Global coal gap between Permian-Triassic extinction and Middle Triassic recovery of peat-forming plants. Geological Society of America Bulletin, 108, 195-207.

Rigby, J. F. (1977). New collections of Triassic plants from the Esk Formation, southeast Queensland. Queensland Government Mining Journal, 78, 320-325.

Rigby, J. F. (1978). Jurassic plant fossils from the Walloon Coal Measures at Rosewood Consolidated Colliery. Queensland Government Mining Journal, 78, 320-325.

Riley, T. R., Crame, J. A., Thomson, M. R. A., \& Cantrill, D. J. (1997). Late Jurassic (Kimmeridgian-Tithonian) macrofossil assemblage from Jason Peninsula, Graham Land: evidence for a significant northward extension of the Latady Formation. Antarctic Science, $9,434-442$

Rothwell, G. W., \& Stockey, R. A. (2002). Anatomically preserved Cycadeoidea (Cycadeoidaceae), with a reevaluation of systematic characters for the seed cones of Bennettitales. American Journal of Botany, 89, 1447-1458.

Rothwell, G. W., Crepet, W. L., \& Stockey, R. A. (2009). Is the anthophyte hypothesis alive and well? New evidence from the reproductive structures of Bennettitales. American Journal of Botany, 96, 296-322.

Rozefelds, A. C., \& Sobbe, I. (1983). Fossil plants of the Durikai plant beds near Warwick, south east Queensland. The Fossil Collector Bulletin, 10, 15-20.

Russell, N. J. (1994). A palaeothermal study of the Clarence-Moreton Basin. Australian Geological Survey Organisation Bulletin, 241, 237-276.

Sahni, B. (1932). A petrified Williamsonia (W. sewardiana, sp. nov.) from the Rajmahal Hills, India. Palaeontologia Indica, 20, 1-19.

Sahni, B., \& Rao, A. R. (1934). Rajmahalia paradoxa gen. et sp. nov. and other Jurassic plants from the Rajmahal Hills. Proceedings of the Indian Academy of Sciences, 1, 258-269.

Saiki, K., \& Yoshida, Y. (1999). A new bennettitalean trunk with unilocunar five-trace nodal structure from the Upper Cretaceous of Hokkaido, Japan. American Journal of Botany, 86, 326-332.

Sandberger, F. v. (1864). Die Flora der oberen Steinkohlenformation im badischen Schwarzwalde. Verhandlungen des naturwissenschaftlichen Vereins in Karlsruhe, 1, 30-36.

Sander, P. M., Gee, C. T., Hummel, J., \& Clauss, M. (2010). Mesozoic plants and dinosaur herbivory. In C. T. Gee (Ed.), Plants in Mesozoic Time: morphological innovations, phylogeny, ecosystems (pp. 331359). Bloomington: Indiana University Press.

Saporta, G. d. (1875). Paléontologie Française ou Description des Fossiles de la France-2e Série-Végétaux. Paris: Masson.
Saporta, G. (1891). Paléontologie francaise ou description des fossils de la France (2, Végétaux). Plantes Jurassiques, 4. Paris: G. Masson, $355-548$.

Schweitzer, H.-J., \& Kirchner, M. (2003). Die rhäto-jurassischen Floren des Iran und Afghanistans: 13. Cycadophyta III. Bennettitales. Palaeontographica B, 264, 1-166.

Seward, A. C. (1913). Contributions to our knowledge of Wealden floras, with especial reference to a collection of plants from Sussex. Quarterly Journal of the Geological Society, London, 69, 85-116.

Sharma, B. D. (1970). On the structure of the seeds of Williamsonia collected from the Middle Jurassic rocks of Amarjola in the Rajmahal Hills, India. American Journal of Botany, 34, 1071-1078.

Sharma, B. D. (1973). Indische Williamsonien-ihr Erhaltungszustand und ihr Bauplan. Zeitschrift für geologische Wissenschaften, 1, 311317.

Sharma, B. D. (1975). Observations on Williamsonia sewardiana Sahni from Amarjola, Rajmahal Hills, India. Časopis pro mineralogii a geologii, 20, 31-37.

Sharma, B. D. (1977). Indian Williamsonias - an illustrated review. Acta Palaeobotanica, 18, 19-29.

Shirley, J. (1898). Additions to the fossil flora of Queensland, mainly from the Ipswich Formation, Trias-Jura system. Geological Survey of Queensland Bulletin, 7, 1-25.

Skwarko, S. K. (1966). Cretaceous stratigraphy and palaeontology of the Northern Territory. Bureau of Mineral Resources, Australia, Bulletin, 73, 1-135.

Solms-Laubach, H. (1891). On the fructification of Bennettites gibsonianus, Carr. Annals of Botany, 5, 419-454.

Srivastava, S. K. (1976). The fossil pollen genus Classopollis. Lethaia, 9 , 437-457.

Srivastava, S. K. (1994). Evolution of Cretaceous phytogeoprovinces, continents and climates. Review of Palaeobotany and Palynology, $82,197-224$.

Stockey, R. A., \& Rothwell, G. W. (2003). Anatomically preserved Williamsonia (Williamsoniaceae): Evidence for bennettitalean reproduction in the Late Cretaceous of Western North America. International Journal of Plant Sciences, 164, 251-262.

Strullu-Derrien, C., McLoughlin, S., Philippe, M., Mørk, A., \& Strullu, D. G. (2012). Arthropod interactions with bennettitalean roots in a Triassic permineralized peat from Hopen, Svalbard Archipelago (Arctic). Palaeogeography, Palaeoclimatology, Palaeoecology, 348-349, 45-58.

Suzuki, W. (1987). Comparative ecology of Rubus species (Rosaceae) I. Ecological distribution and life history characteristics of three species, R. palmatus var. coptophyllus, R. microphyllus and $R$. crataegifolius. Plant Species Biology, 2, 85-100.

Svenson, D., Taylor, D. A. (1975) Styx Basin, Q. In D. M. Traves \& D. King (Eds), Economic Geology of Australia and Papua New Guinea-2. Coal. Melbourne: AusIMM Monograph Series 6, 324-327.

Sze, H. C. (1936). Über einen Vorläufer von Pterophyllen in der unteren Shihhotze Serie in Shansi. Bulletin of the Geological Society of China, 15, 467-476.

Taylor, T. N., Taylor, E. L., \& Krings, M. (2009). Paleobotany-the biology and evolution of fossil plants. Burlington/Amsterdam: Academic Press/Elsevier.

Tenison-Woods, J. E. (1884). On the fossil flora of the coal deposits of Australia. Proceedings of the Linnean Society of New South Wales, $8,37-167$.

Thomas, H. H., \& Bancroft, N. (1913). On the cuticles of some recent and fossil cycadean fronds. Transactions of the Linnean Society of London: Botany, 8, 155-204.

Tidwell, W. D., \& Clifford, H. T. (1995). Three new species of Millerocaulis (Osmundaceae) from Queensland, Australia. Australian Systematic Botany, 8, 667-685. 
Tidwell, W. D., \& Rozefelds, A. C. (1990). Grammatocaulis donponii gen. et sp. nov., a permineralized fern from the Jurassic of Queensland, Australia. Review of Palaeobotany and Palynology, 66, 147-158.

Tidwell, W. D., Kim, J.-H., \& Kimura, T. (1987). Mid-Mesozoic leaves from near Ida Bay, Southern Tasmania. Papers and Proceedings of the Royal Society of Tasmania, 121, 159-170.

Turner, S., Bean, L. B., Dettmann, M., McKellar, J., McLoughlin, S., \& Thulborn, T. (2009). Australian Jurassic sedimentary and fossil successions: current work and future prospects for marine and nonmarine correlation. GFF, 131, 49-70.

Vajda, V., \& McLoughlin, S. (2004). Fungal proliferation at the Cretaceous-Tertiary boundary. Science, 303, 1489.

Vajda, V., Raine, J. I., \& Hollis, C. J. (2001). Indication of global deforestation at the Cretaceous-Tertiary boundary by New Zealand fern spike. Science, 294, 1700-1702.

Vaughan, A. P. M., \& Storey, B. C. (2007). A new supercontinent selfdestruct mechanism: evidence from the Late Triassic-Early Jurassic. Journal of the Geological Society, 164, 383-392.

Vavrek, M. J., Larsson, H. C. E., \& Rybczynski, N. (2008). A Late Triassic flora from east-central Axel Heiberg Island, Nunavut, Canada. Canadian Journal of Earth Sciences, 44, 1653-1659.

Veevers, J. J. (Ed.). (2000). Billion-year Earth history of Australia and neighbours in Gondwanaland. Sydney: GEMOC Press.

Wachtler, M., \& van Konijnenburg-van Cittert, J. H. A. (2000). The fossil flora of the Wengen Formation (Ladinian) in the Dolomites (Italy). Beiträge zur Paläontologie, 25, 105-141.

Walkom, A. B. (1917). Mesozoic floras of Queensland. Part 1.-concluded. The flora of the Ipswich and Walloon Series. (d.) Ginkgoales, (e.) Cycadophyta, (f.) Coniferales. Geological Survey of Queensland Publication, 259, 1-49.

Walkom, A. B. (1919). Mesozoic floras of Queensland. Parts 3 and 4. The floras of the Burrum and Styx River Series. Geological Survey of Queensland Publication, 263, 1-77.

Walkom, A. B. (1921). On the occurrence of Otozamites in Australia, with descriptions of specimens from Western Australia. Proceedings of the Linnean Society of New South Wales, 46, 147-153.

Walkom, A. B. (1924). On fossil plants from Bellevue near Esk. Memoirs of the Queensland Museum, 8, 77-92.

Walkom, A. B. (1928). Fossil plants from the Esk district, Queensland. Proceedings of the Linnean Society of New South Wales, 53, 458468.

Watson, J., \& Lydon, S. J. (2004). The bennettitalean trunk genera Cycadeiodea and Monanthesia in the Purbeck, Wealden and Lower Greensand of southern England: a reassessment. Cretaceous Research, 25, 1-26.
Watson, J., \& Sincock, C. A. (1992). Bennettitales of the English Wealden. London: Monograph of the Palaeontographical Society.

Webb, J. A. (1982a). Triassic radiometric dates from eastern Australia. In G. S. Odin (Ed.), Numerical Dating in Stratigraphy (pp. 515-521). New York: John Wiley.

Webb, J. A. (1982b). Triassic species of Dictyophyllum from eastern Australia. Alcheringa, 6, 79-91.

Webb, J. A. (1983). A new plant genus, possibly a marattialean fern, from the Middle Triassic of eastern Australia. Association of Australasian Palaeontologists Memoir, 1, 363-371.

Webb, J. A. (2001). A new marattialean fern from the Middle Triassic of eastern Australia. Proceedings of the Linnean Society of New South Wales, 123, 215-224.

Weber, R. (2008). Dictyotrichia gen. nov., Haitingeria Krasser, y otrogos órganos reproductivos o apendiculares de cicadofitas, Triásico Tardío, Sonora, México. Universidad Nacional Autónoma de México, Instituto de Geología, Boletín, 115, 117-149.

Wells, A. T., \& O'Brien, P. E. (1994). Lithostratigraphic framework of the Clarence-Moreton Basin. In A. T. Wells \& P. E. O'Brien (Eds.), Geology and Petroleum Potential of the Clarence-Moreton Basin, New South Wales and Queensland (Vol. 241, pp. 4-47). Canberra: AGSO, Bulletin.

White, M. E. (1961). Report on 1960 collections of Mesozoic plant fossils from the Northern Territory. Bureau of Mineral Resources, Geology and Geophysics, Australia, Record 1961/146, 1-26. (unpublished).

White, M. E. (1986). The Greening of Gondwana. Sydney: Reed Books.

White, M. E. (1991). Time in our Hands. Sydney: Reed Books.

Wieland, G. R. (1899). A study of some American fossil cycads. Part III. The female fructification of Cycadeoidea. American Journal of Science, 4th Series, 7, 383-391.

Wieland, G. R. (1906). American fossil cycads-volume I: structure. Washington: Carnegie Institution.

Wieland, G. R. (1909). The williamsonias of the Mixteca Alta. Botanical Gazette, 48, 427-441.

Wieland, G. R. (1911). On the williamsonian tribe. American Journal of Science, 32, 433-476.

Wieland, G. R. (1916). American fossil cycads-volume II: taxonomy. Washington: Carnegie Institution.

Williamson, W. C. (1847). On the scaly vegetable heads or collars from Runswick Bay, supposed to belong to Zamia gigas. Proceedings of the Yorkshire Philosophical Society, 1, 45-51.

Williamson, W. C. (1870). Contributions towards the history of Zamia gigas Lindl. \& Hutt. Transactions of the Linnean Society, 26, 663674.

Yates, J. (1847). Notice of Zamia gigas. Proceedings of the Yorkshire Philosophical Society, 1, 37-42. 